\title{
Whimsical Punishment: The Vice of Federal Intervention, Constitutionalization, and Substantive Due Process in Punitive Damages Law
}

\author{
Jenny Miao Jiang $\nmid$
}

\section{INTRODUCTION}

In Pacific Mutual Life Insurance Co. v. Haslip, ${ }^{1}$ the Supreme Court constitutionalized the law of punitive damages and subjected punitive awards to due process limitations. ${ }^{2}$ Since Haslip, the Court has struggled continuously to bring uniformity to its punitive damages jurisprudence. Despite the Court's best efforts, however, punitive damages law continues to be erratically applied, and thus, has not satisfied the due process concerns articulated by the Court. This Comment puts forward recommendations for improving punitive damages law in light of the Court's constitutional concerns.

In BMW of North America, Inc. v. Gore, ${ }^{3}$ the Court established a federal standard for assessing the constitutionality of punitive damages

Copyright (C) 2006 California Law Review, Inc. California Law Review, Inc. (CLR) is a California nonprofit corporation. CLR and the authors are solely responsiblc for the content of their publications.

$\dagger \quad$ J.D. Candidate, School of Law, University of California, Berkeley (Boalt Hall), 2006; B.A., University of Califomia, Santa Cruz, 2003; e-mail: jennymjiang@yahoo.com. I am deeply indebted to Elizabeth Cabraser for her support and guidance, without which this Comment would not have been possible. I am grateful to Aimée Buckland, Geoff Painter, Rebecca Hart, Elizabeth Jin, Peter Brachman, Tina Wong, and my other colleagues on the California Law Review, for their careful edits and valuable intellectual contributions; to Natalie Lents, Shawn Bayern, Dean Harvey, and Sheryl Lawrence, for their honest and thoughtful input on earlier drafts. 1 am also grateful to Alex $\mathrm{Ng}$ of Weil, Gotshal \& Manges, whose "tough love" has helped me in more ways than he will ever know. Finally, many thanks to Professors Susan Poser, David Sklansky, and John Yoo, for their continued inspiration, encouragement, and mentorship; and to my parents, for their love and unwavering support.

I. 499 U.S. I (I99I) [Haslip].

2. Id. at I8. In an earlier case, the Supreme Court rejected an Eighth Amendment challenge to a punitive damages award, holding that the "excessive fines" provision applied only to governmental actions and could not be used to limit damages awards in civil suits between private litigants. See Browning-Ferris Inds. of Vermont v. Kelco Disposal, Inc., 492 U.S. 257, 262-76 (1989); see also U.S. Const. amend. VIII.

3. 517 U.S. 559 (1996) [BMW]. 
awards. ${ }^{4}$ The $B M W$ standard considered three factors: (1) reprehensibility, (2) harm, and (3) comparable penalties. ${ }^{5}$ The Court followed $B M W$ with Cooper Industries, Inc. v. Leatherman Tool Group, Inc., ${ }^{6}$ where it held that trial courts' awards of punitive damages are subject to appellate review on a de novo standard. ${ }^{7}$ Recently, in another ambitious effort to promote uniformity in its punitive damages law, the Court expounded upon the principles of BMW in State Farm Mutual Automobile Insurance Co. v. Campbell [State Farm I]. ${ }^{8}$ Although State Farm I did not add any "new, free-standing factor to the constitutional analysis of punitive damages," it sought to clarify the Court's past articulations, and to bring those articulations into sharper focus. ${ }^{9}$

This Comment argues that State Farm I has failed to effectuate the Court's goal of promoting uniformity. Indeed, State Farm I, like the cases that came before it, raises more questions about punitive damages law than it actually answers. For example, after State Farm I, do we really have a clearer idea of what "reprehensible" conduct entails? Or does the notion of reprehensibility, "like truth and beauty, [remain as] subjective" as it has ever been? ${ }^{10}$ Ambiguities also persist with respect to the second and third $B M W$ factors, which address the issues of harm and comparable penalties. After State Farm I, we know that the court assessing the award-to-harm ratio must take into account both "actual" and "potential" harm. But how do we go about measuring potential harm? Do we focus exclusively on the additional harm that defendant could have caused to plaintiff, or do we also account for the harm that defendant could have caused to the public at large, as well?" With respect to comparability, we know that State Farm I limits the utility of criminal penalties. But does "less utility"12 mean no

4. Id. at 574-86.

5. See $B M W, 517$ U.S. at $575-85$ (setting forth these three criteria as the test of constitutionality for punitive damages cases). These criteria are discussed in more detail in Part I.A.1-3, infra.

6. 532 U.S. 424 (2001) [Cooper].

7. Id. at 431,435 . According to the Court, de novo review tends to unify precedent, stabilize the law, and help "to assure the uniform general treatment of similarly situated persons that is the essence of law itself." Id. at 436.

8. 538 U.S. 408 (2003) [State Farm I].

9. See In re Exxon Valdez, 296 F. Supp. 2d 1071, 1076 (D. Alaska 2004) [Exxon Valdez] (assessing the precedential impact of State Farm $I$ ).

10. See id. at 1093.

11. See Exxon Valdez, 296 F. Supp. 2d at 1103-04 (defining potential harm to mean both harm that defendant could have caused to plaintiffs and harm that defendant could have caused to the public at large); Williams v. Philip Morris Inc., 92 P.3d 126, 144-45 (Or. Ct. App. 2004), aff'd, 2006 Ore. LEXIS 31 (Or. 2006) (defining potential harm to mean only harm that defendant eould have caused to the public at large); cf. Henley v. Philip Morris Inc., 5 Cal. Rptr. 3d 42, 85 (Cal. Ct. App. 2003) (excluding potential harm completely from the award-to-harm ratio analysis).

12. See State Farm I, 538 U.S. at 428. 
utility at all, or can lower courts continue to take criminal penalties into account-albeit on a more limited basis--in their constitutional analyses? ${ }^{13}$

This Comment attempts to address some of these questions, and to explore the implications of these questions on the current state of punitive damages law. This Comment also sets forth two recommendations for improving punitive damages law. The first recommendation works within the preexisting legal framework, proposing that instead of measuring the reasonableness of punitive awards through amorphous concepts like "reprehensibility," "comparability," or "potential harm," there should be a specific set of guidelines targeted at meting out punitive damages awards $\mathrm{m}$ the civil context. These guidelines would resemble the Federal Sentencing Guidelines, currently utilized in the criminal context. ${ }^{14}$ In other words, these guidelines would set forth the circumstances under which awards of punitive damages may be imposed and provide for aggravating and mitigating factors potentially giving rise to adjustments of these awards. The guidelines would additionally be keyed to a numerical grid specifically designed to correlate the gravity of defendants' misconduct with their punitive damages eligibility. ${ }^{15}$

The second recommendation that this Comment proposes does not work within the preexisting punitive damages framework, but challenges this framework head-on. Under this recommendation, courts would no longer be required to assess the substance of punitive damages awards, but would need only to review such awards for procedural due process compliance. In other words, this recommendation argues that because the Supreme Court has failed to achieve the goal of uniformity in punitive damages law, it should no longer hold substantive assessments of punitive damages awards to federalized standards of "reasonableness." To the contrary, the Court should return responsibility for making such assessments to the states, where it traditionally had been prior to the Court's intervention in Haslip.

Part I of this Comment provides an introduction to the current punitive damages framework. Part II analyzes this framework and highlights

13. See Mathias v. Accor Econ. Lodging, Inc., 347 F.3d 672, 678 (7th Cir. 2003) (citing to the state criminal statute on reckless endangerment in assessing the constitutionality of the punitive damages award); Exxon Valdez, 296 F. Supp. 2d at I107 (citing to multiple criminal statutes under which defendant was charged, in determining the constitutionality of the punitive award at issue); $f$. Romo v. Ford Motor Co., 6 Cal. Rptr. 3d 793, 812 (Cal. Ct. App. 2003) (declining specifically to take criminal penalties into account in assessing the constitutionality of the punitive award at issue).

14. In the recent case of United States v. Booker, the Supreme Court held the mandatory application of the Federal Sentencing Guidelines to be violative of criminal defendants' Sixth Amendment right, but continued to permit use of the Guidelines on an "advisory" basis. See 543 U.S. 220 (2005). The potential implications of the Booker decision in the punitive damages context are discussed in Part Ill.A.4, infra.

15. For illustrative purposes, a case study applying a set of proposed punitive damages guidelines to the facts of State Farm I is set forth in Part III.A.2, infra. 
the inconsistencies therein, arguing that the existence of these inconsistencies undermine the Court's goals of promoting uniformity and ensuring fair notice in this area of law. Part III of this Comment proposes two recommendations for improving punitive damages law. Although the recommendations cannot purport to solve all of the problems underlying the erratic awards of punitive damages, they do seek to push the current dialogue on punitive damages jurisprudence in a mo1e constructive direction.

I

\section{LEGAL BACKGROUND}

The Supreme Court has traditionally taken a relatively laissez-faire approach toward punitive damages law, viewing punitive awards as a discretionary function of the state common law courts. ${ }^{16}$ Browning-Ferris Industries of Vermont, Inc. v. Kelco Disposal, Inc. ${ }^{17}$ represents the first instance in which the Court suggested that punitive damages awards may pose problems of a constitutional magnitude. ${ }^{18}$ In that case, defendant claimed that the punitive damages award leveled against him violated his Eighth Amendment protection against "excessive fines." 19 The Court rejected defendant's argument but suggested, in dictum, that punitive damages awards could potentially be subject to other constitutional constraints, namely, the Due Process Clause of the Fourteenth Amendment. ${ }^{20}$

Two years later, in Haslip, the Court formally brought punitive damages law within the ambit of the Fourteenth Amendment. There, the Court upheld a state-imposed punitive damages award against a constitutional challenge, ${ }^{21}$ holding that the award satisfied both procedural and substantive due process. ${ }^{22}$ The award satisfied procedural due process because it limited jury discretion and provided defendants with adequate post-verdict appellate review. ${ }^{23}$ The Court also examined the substance (i.e., amount) of the award and concluded that it did "not cross the line into the area of constitutional impropriety." 24

16. See Steven L. Chanenson \& John Y. Gotanda, The Foggy Road for Evaluating Punitive Damages: Lifting the Haze from the BMW/State Farm Guideposts, 37 U. MICH. J.L. ReForm 441, 449 (2004).

17. 492 U.S. 257 (1989).

18. See id. at 276-77.

19. See U.S. Const. amend. VIIl; see also supra note 2 and accompanying text.

20. See Browning-Ferris, 492 U.S. at 276-77 (noting that "whether due process acts as a check on undue jury discretion to award punitive damages ... [is an] inquiry [that] must await another day"); see also U.S. CONST. amend. XIV, §1.

21. See Haslip, 499 U.S. 1, 17-19 (1991).

22. Id. at 18-23 (assessing the procedural element of the punitive damages award); id. at 23-24 (assessing the substantive element of the punitive damages award).

23. Id. at 19.

24. Id. at 23-24. 


\section{A. Three Factors for Assessing Punitive Damages Awards}

Having established that punitive damages law falls squarely within the scope of the Due Process Clause, the Court next sought to prescribe a uniform standard with which to measure the constitutionality of punitive awards. The opportunity to prescribe such a standard came in 1996, with the Court's decision in $B M W{ }^{25}$

In $B M W$, the trial court awarded plaintiff $\$ 2$ million in punitive damages, upon the jury's determination that defendant had committed "gross, oppressive or malicious fraud." 26 The Supreine Court reversed, holding that the award, which was 500 times the amount of plaintiff's compensatory damages, was "grossly excessive" and violated defendant's substantive due process rights. ${ }^{27}$ In so holding, the $B M W$ Court articulated three factors for assessing the constitutionality of punitive damages awards. ${ }^{28}$ The first factor looked at the reprehensibility of a defendant's conduct. ${ }^{29}$ The second factor examined the ratio between plaintiff's punitive damages award and the actual or potential harm that plaintiff had suffered, as measured through his compensatory award (i.e., the award-to-harm ratio). ${ }^{30}$ The third factor compared plaintiff's punitive damages award against the other penalties that defendant could have incurred for engaging in similar misconduct. ${ }^{31}$ The Court recently revisited, and reaffirmed the $B M W$ factors in State Farm I. ${ }^{32}$

\section{The First BMW Factor: Reprehensibility}

In State Farm I, the majority sought to elucidate the first $B M W$ factor by providing a set of sub-rules that should be taken into account in assessing defendant's reprehensibility. The first sub-rule asks whether the harm that defendant caused was physical or economic in nature. The second subrule examines whether defendant's tortious conduct evinced an indifference to, or a reckless disregard, for the health or safety of others. The third sub-rule focuses on whether plaintiff was financially vulnerable. The fourth sub-rule examines whether defendant's conduct involved repeated actions or was an isolated incident. The fifth and final sub-rule looks to plaintiff's harm and asks whether this harm was caused by a mere accident, or rather, by defendant's intentional malice, trickery, or deceit. ${ }^{33}$

\footnotetext{
25. 517 U.S. 559 (1996).

26. Id. at 565 . The jury initially awarded plaintiff $\$ 4$ million in punitive damages, but the state supreme court subsequently reduced the award to $\$ 2$ million. $I d$. at 567 .

27. Id. at $585-86$.

28. Id. at $575-85$.

29. See id. at 575 .

30. Id. at 580 (actual harm); id. at 581-82 (potential harm).

31. Id. at 583 .

32. State Farm I, 538 U.S. 408, 418-29 (2003).

33. Id. at 419 (listing the five sub-rules).
} 


\section{The Second BMW Factor: the Award-to-Harm Ratio ${ }^{34}$}

With respect to the second $B M W$ factor, the State Farm I majority affirmed TXO Production Corp. v. Alliance Resources Corp. ${ }^{35}$ and held that courts may take into account both "actual" and "potential" harm in assessing the award-to-harm ratio in a punitive damages case. ${ }^{36}$ However, the majority left one critical question unanswered: what constitutes potential harm $?^{37}$ Is it to be interpreted narrowly, to mean only the additional harm that defendant could have caused to plaintiff, beyond the harm already incurred? Or is potential harm to be measured more broadly, to encompass the harm that defendant could have caused to the public at Iarge, as well? ${ }^{38}$

The State Farm I majority also declined to endorse a bright-line ratio between plaintiff's harm and plaintiff's punitive damages award. ${ }^{39}$ However, it articulated three quasi-rules, which it considered relevant in assessing the permissibility of the award-to-harm ratio. First, the ratio between plaintiff's punitive and compensatory damages awards should be within single digits, and "few awards exceeding a single-digit ratio between punitive and compensatory damages . . . will satisfy due process." Second, if plaintiff's compensatory award is already high, then a lesser ratio between the awards may be justified, since a high compensatory award is generally sufficient, in itself, to make plaintiff whole. ${ }^{41}$ Finally, if plaintiff's compensatory award already includes an apportionment for emotional distress, then a high punitive damages award is more likely to violate due process. This is because damages for emotional distress already contain a

34. No court has officially referred to the second $B M W$ factor as "the award-to-harm ratio." However, the term "award-to-harm ratio" will be used consistently throughout this Comment as a. shorthand reference to the ratio between plaintiff's punitive damages award and actual (and/or potential) harm that plaintiff has suffered.

35. 509 U.S. 443 (1993).

36. State Farm I, 538 U.S. at 424-25.

37. See Exxon Valdez, 296 F. Supp. 2d 1071, 1098 (D. Alaska 2004) (noting that " "potential harm' is often not subject to precise calculation," and further pointing out that while the State Farm I majority held that potential harm could be taken into account in the award-to-harm ratio analysis, the case of State Farm I itself did not actually involve a question of potential harm).

38. See TXO Prod. Corp., 509 U.S. at 460 (explaining that in measuring potential harm, it is "appropriate to consider the magnitude of the potential harm that the defendant's conduct would havc caused to its intended victim if the wrongful plan had succeeded, as well as the possible harm to other victims that might have resulted if similar future behavior werc not deterred"); $c f$. Henley v. Philip Morris Inc., 5 Cal. Rptr. 3d 42, 85 (Cal. Ct. App. 2003) (excluding potential harm altogether from the award-to-harm ratio analysis).

39. See State Farm 1, 538 U.S. at 424-25.

40. See id. at 425 . The State Farm I majority, however, did recognize a potential exception to this quasi-rule: in cases where "a particularly egregious act has resulted in only a small amount of economic damages," a higher award-to-harm ratio may be justified under the Due Process Clause. Id; see also Mathias v. Accor Econ. Lodging, Inc., 347 F.3d 672, 677 (7th Cir. 2003) (applying this exception to uphold a punitive damages award where employees of defendant's motel deliberately rented rooms to guests despite knowing tbat the rooms were infested with bedbugs).

41. The State Farm I majority suggested that in such a case, "a lesser ratio, perhaps only equal to compensatory damages, can reach the outermost limit of the due process guarantee." 538 U.S. at 425. 
built-in punitive element, and layering additional punitive damages on top of the emotional award may be both unnecessarily and unconstitutionally duplicative. $^{42}$

\section{The Third BMW Factor: Comparable Penalties}

In cases prior to State Farm I, the Court, in applying the third $B M W$ factor, had consistently taken into account both civil and criminal penalties. ${ }^{43}$ In State Farm I, however, the majority confined its comparability analysis to civil penalties alone. ${ }^{44}$ It also expressly limited lower courts' ability to take criminal penalties into consideration in their punitive dainages reviews. ${ }^{45}$ According to the State Farm I majority, while the existence of criminal penalties has soine bearing on the seriousness with which a state views a defendant's misconduct, such penalties are of "less utility" when used to determine the dollar amount of a punitive damages award. ${ }^{46}$

II

A FALTERING SYSTEM:

Analysis of the Current Punitive Damages Framework

Despite the State Farm I majority's best efforts to create a more cohesive punitive damages framework through the use of the $B M W$ factors, it has resoundingly failed to achieve this result. This section analyzes the $B M W$ factors in depth, and demonstrates the many ways in which they have been inconsistently applied by the lower courts. This section concludes by arguing that the inconsistent application of the $B M W$ factors casts significant doubt upon the Supreme Court's ability to achieve due process compliance through application of its current body of punitive damages jurisprudence.

\section{A. Reprehensibility in the Shadow of the State Farm 1 Dialogue}

In his opinion in Exxon Valdez, Judge H. Russel Holland noted that the "reprehensibility of a party's conduct, like truth and beauty, is subjective. One's view of the quality of an actor's conduct is the result of complex value judgments." ${ }^{47}$ In State Farm I, a majority of the Supreme Court attempted to bring some level of objectivity to the inherently

42. See id. at 426 .

43. See, e.g., BMW, 559 U.S. at 583-84; Haslip, 499 U.S. 1, 23 (1991).

44. State Farm I, 538 U.S. at 428.

45. Id. Concern for defendant's procedural due process rights may have motivated the majority's decision to exclude criminal penalties from its comparability analysis. To this effect, the majority admonished: "Great care must be taken to avoid use of the civil process to assess criminal penalties that can be imposed only after the heightened protections of a criminal trial have been observed, including, of course, its higher standards of proof." $I d$.

46. Id.

47. Exxon Valdez, 296 F. Supp. 2d 1071, 1093 (D. Alaska 2004). 
subjective reprehensibility analysis by promulgating a series of sub-rules for lower courts to consider when evaluating defendants' misconduct. ${ }^{48}$ As evidenced by the ultimate disposition of State Farm I itself, however, these sub-rules have, in fact, done very little in the way of promoting uniformity.

State Farm I arose out of an automobile accident in which plaintiff was clearly at fault. ${ }^{49}$ State Farm, plaintiff's insurer, refused to settle the claim with the accident victim's estate and took the case to trial, where it lost. State Farm then refused to pay plaintiff's liability and suggested that plaintiff sell his house to satisfy the judgment. ${ }^{50}$ Although State Farm eventually paid the judgment, plaintiff nevertheless sued State Farm for bad faith, fraud, and emotional distress. At trial, the jury leveled \$145 million in punitive damages against State Farm. ${ }^{51}$

The Supreme Court reversed, holding that while State Farm's conduct "certainly merit[ed] no praisc," 52 it was not so reprehensible as to warrant the punishment that had been leveled against it. ${ }^{53}$ The Court relied on three factors in its holding. The Court first noted that plaintiff's injury was of an economic, rather than a physical, nature-i.e., State Farm had merely refused to pay plaintiff's insurance benefits when such benefits were due. ${ }^{54}$ Failure to discharge an economic obligation is much less reprehensible than, say, murder, torture, or deliberate poisoning of the environment, ${ }^{55}$ and should be treated accordingly. Next, the Court pointed out that plaintiff's "economic" harm was, in fact, minor, ${ }^{56}$ at the time that plaintiff filed suit, State Farm had already paid the judgment arising out of the initial accident. ${ }^{57}$ Finally, the Court held that the punitive damages award could not be justified on grounds that State Farm had caused plaintiff emotional distress as any such distress would already have been factored into the jury's calculation of plaintiff's compensatory damages award. ${ }^{58}$ The Court therefore vacated the $\$ 145$ million punitive damages award against State Farm and remanded the case to the Utah Supreme Court for reconsideration. ${ }^{59}$

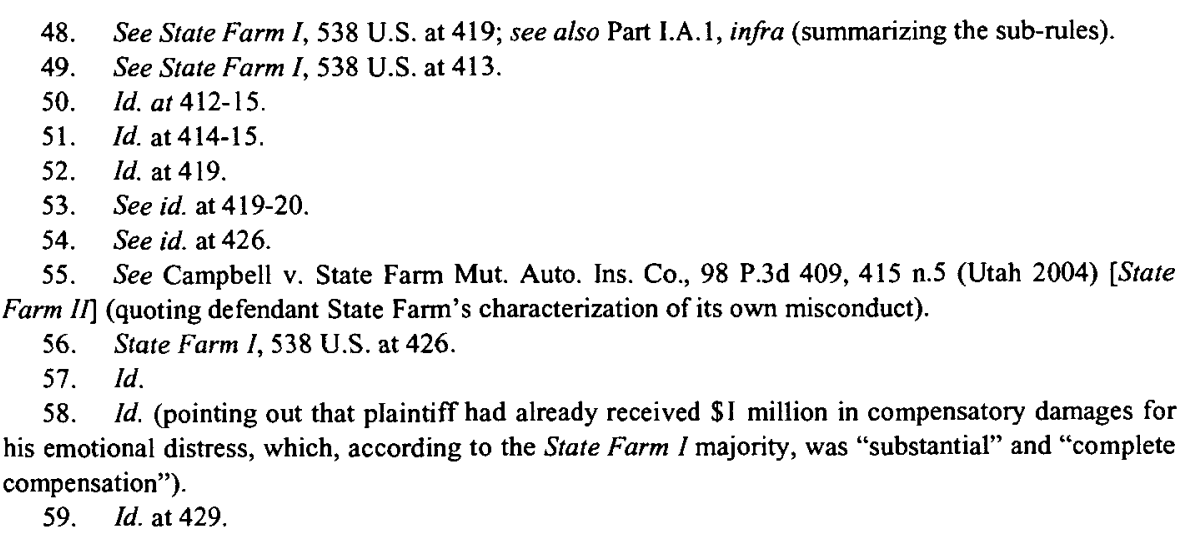


On remand, the Utah Supreme Court examined the same facts and applied the same legal standard as the U.S. Supreme Court. ${ }^{60}$ However, it arrived at a wholly different conclusion on the issue of reprehensibility, thus illustrating the lack of uniformity in the current state of punitive damages law notwithstanding the U.S. Supreme Court's heavy-handed guidance. While the U.S. Supreme Court characterized the harm that plaintiff had suffered as economic, the Utah Supreme Court vehemently disputed this characterization. Writing for a unanimous panel, Justice Nehring stated point-blank, "It simply will not do to classify [plaintiff"s] injury as solely 'economic' for the purposes of evaluating it under the first prong of the $[B M W]$ reprehensibility test, and we decline to do so."

Instead, the Utah Supreme Court held that the harm that State Farm inflicted upon plaintiff was "more closely akin to physical assault or trauma than to mere economic loss." $"$ The court found this to be so for several reasons. According to the Utah Supreme Court, individuals purchase insurance policies not only to provide for funds in cases of loss, but also to protect their own peace of mind. ${ }^{63}$ When an insurer wrongfully denies benefits to an insured individual, then, it not only causes harm to the individual's economic well-being by depriving him of expected funds, but also causes harm to the individual's emotional and physical health by "callously betray[ing his] expectation of peace of mind."64 The Utah Supreme Court also noted that additional factors aggravated State Farm's failure to pay. State Farm had unnecessarily subjected plaintiff to the "risks and rigors" of a trial, the outcome of which should have been clear from the outset. ${ }^{65}$ Moreover, even after the trial, State Farm had continued to act egregiously toward plaintiff, refusing to pay the judgment and suggesting that plaintiff sell his house in order to "get things moving." of these considerations, the Utah Supreme Court concluded that State Farm's misconduct caused plaintiff a "profound noneconomic injury,"67 and was therefore, sufficiently reprehensible to justify the imposition of a very high punitive damages award against it. ${ }^{68}$

60. See State Farm II, 98 P.3d at 414 (restating, nearly verbatim, the reprehensibility sub-rules that the U.S. Supreme Court had articulated in State Farm I).

61. Id. at 416 .

62. Id. at 415 .

63. Id.

64. Id.

65. See id. at 416

66. See State Farm I, 538 U.S. at 413.

67. State Farm II, 98 P.3d at 416.

68. Id. at 420 . To comply with the letter (but arguably, not the spirit) of the remand order, the Utah Supreme Court reduced plaintiff's punitive damages award from $\$ 145$ million to $\$ 9$ million. Id. After State Farm II, defendant State Farm again petitioned the U.S. Supreme Court for certiorari. Certiorari was summarily denied on October 4, 2004. See State Farm Mut. Auto. Ins. Co. v. Campbell, 543 U.S. 874 (2004). 
The dialogue between the U.S. Supreme Court and the Utah Supreme Court in the State Farm case vividly illustrates the fluidity of the reprehensibility concept. In this case, two courts, examining the same facts and applying the same law, reached two profoundly different conclusions on the issue of reprehensibility. The U.S. Supreme Court concluded that while defendant deserved a slap on the wrist for engaging in conduct that "merit[ed] no praise," anything more than that would constitute excessive punishment violative of defendant's substantive due process rights. The Utah Supreme Court, in contrast, appeared utterly appalled by defendant's conduct. This court condemned such conduct as "egregious,"69 "abusive," and "odious," level of punishment. The fact that two courts, in a single case, could arrive at two conclusions so fundamentally at odds with one another belies the notion that uniformity in punitive damages law has been, or is even close to being, achieved through constitutionalization vis-à-vis the Due Process Clause.

\section{B. The Award-to-Harm Ratio: Actual vs. Potential Harm}

In TXO Production Corp. v. Alliance Resources Corp., the Supreme Court held that in assessing the constitutionality of punitive damages awards, the reviewing court should take into account both actual and potential harm. ${ }^{72}$ In State Farm I, the majority reaffirmed TXO's position, holding that "the disparity between the actual or potential harm suffered by plaintiff and the punitive damages award" should be assessed when reviewing the award for constitutionality. ${ }^{73}$ The State Farm I majority, however, failed to elaborate on what "potential harm" means. ${ }^{74}$ This omission has caused substantial confusion in the lower courts, as judges on both the federal and state levels have struggled to define the term "potential harm" and to conduct the award-to-harm ratio analysis in a way consistent with their own, unique definitions. The wide array of ways that the lower courts have defined "potential harm" has created significant ambiguities in punitive damages law. These ambiguities, in turn, have undermined the Supreme Court's goals of promoting uniformity and addressing due process concerns. Two cases arising out of analogous facts best serve to illustrate this troubling phenomenon.

\footnotetext{
69. State Farm $I I, 98$ P.3d at 420.

70. Id. at 414 .

71. Id. at $415 \mathrm{n} .5$.

72. 509 U.S. 443,460 (1993).

73. State Farm I, 538 U.S. at 418 (emphasis added).

74. See Exxon Valdez, 296 F. Supp. 2d 1071, 1098 (D. Alaska 2004).
} 


\section{The Philip Morris Cases: Common Facts}

Henley v. Philip Morris Inc. ${ }^{75}$ and Williams v. Philip Morris Inc. ${ }^{76}$ involve the same defendant and arise out of the same course of conduct. The common facts of Henley and Williams, as established through their respective trials, are as follows: During the period from 1953 to the 1990s, mounting scientific evidence linked health risks to cigarette smoking. In response, defendant Philip Morris, working in conjunction with other cigarette manufacturers, launched a public relations campaign aimed at denying any correlations between smoking and serious illness. Though defendant never expressly asserted that cigarette smoking was safe, it attempted to undermine any scientific evidence presented against smoking. Through its campaign, defendant hoped to perpetuate the illusion that a legitimate controversy existed as to whether cigarette smoking was dangerous to human health. Evidence at the Henley and Williams trials also supported the finding that defendant knew, from the outset, that tobacco contained numerous carcinogenic substances. Defendant was also aware of the numerous and damning epidemiological studies, which strongly linked smoking to lung cancer. In the face of all this information, defendant nevertheless chose to press forward with its public relations campaign. ${ }^{77}$

It is against this backdrop that the California and Oregon Courts of Appeal reviewed the constitutionality of the punitive damages awards leveled against Philip Morris. In reviewing these awards, the Henley and Williams courts each ascribed an independent meaning to the term "potential harm." These disparate definitions of "potential harm" radically altered the outcomes of the two courts' award-to-harm ratio analyses and, ultimately, the outcomes of the cases themselves.

\section{Henley: Wholesale Exclusion of Potential Harm}

In Henley, a personal injury case, a California jury awarded plaintiff $\$ 1.5$ million in compensatory damages and $\$ 50$ million in punitive damages. ${ }^{78}$ The trial court reduced plaintiff's punitive damages award to $\$ 25$ million and defendant appealed. ${ }^{79}$ The California Court of Appeal further reduced plaintiff's award, holding that the seventeen-to-one ratio between plaintiff's compensatory and punitive damages awards was excessive and could not survive the Supreme Court's decision in State Farm $I .{ }^{80}$ In so holding, the court focused exclusively on the actual harm that plaintiff had

\footnotetext{
75. 5 Cal. Rptr. 3d 42 (Cal. Ct. App. 2003).

76. 92 P.3d 126 (Or. Ct. App. 2004), aff'd, 2006 Ore. LEXIS 31 (Or. 2006).

77. See Henley, 5 Cal. Rptr. 3d at 51; Williams, 92 P.3d. at 127-29.

78. Henley, 5 Cal. Rptr. $3 \mathrm{~d}$ at 50.

79. See Id.

80. Id at 85 . The California Court of Appeal consequently reduced plaintiff's punitive damages award from $\$ 25$ million (17-to-1 ratio) to $\$ 9$ million (6-to-1 ratio). Id.
} 
suffered, as measured by plaintiff's compensatory award. ${ }^{81}$ Specifically, the Henley court noted, "as we read [State Farm I], a double-digit ratio will be justified rarely, and perhaps never in a case where the plaintiff has recovered an ample award of compensatory damages." 82 Since plaintiff in Henley had already recovered $\$ 1.5$ million in compensatory damages, a punitive damages award approximately seventeen times that size was clearly unconstitutional under State Farm $I$.

It is important to note that although the Henley court did not expressly take into account measures of potential harm in its award-to-harm ratio analysis, it did recognize the existence of such harm. For example, in its discussion of the first $B M W$ factor, the Henley court noted that defendant's perpetuation of its public relations campaign was particularly reprehensible because it persuaded "millions of youngsters, including plaintiff . . to participate in a habit that was likely to, and did, bring many of them to early illness and death." ${ }^{23}$ And in rejecting defendant's argument that the jury had impermissibly considered evidence of defendant's out-of-state conduct, the Henley court explained: "[p]laintiff's claims ... rest on a quintessential 'mass tort,' i.e., a course of more-or-less uniform conduct directed at the entire public and maliciously injuring, through a system of interconnected devices, an entire category of persons to which plaintiff squarely belongs." ${ }^{94}$ Notwithstanding the Henley court's recognition that defendant's acts potentially caused harm to many individuals other than plaintiff, it ultimately declined to take such harm into consideration in its award-to-harm ratio analysis. ${ }^{85}$

\section{Williams: Measuring Potential Harm to the General Public}

The Henley court's failure to account for potential harm in its awardto-harm ratio analysis contrasts sharply with Williams, an Oregon case with

81. See id.; see also id. at 82 n.20 (noting that in measuring reprehensibility, the court only "focus[ed] on the conduct contributing to plaintiff's own injuries").

82. Id. at 85 .

83. Id. at $81-82$

84. Id. at 83 .

85. Compare Bullock v. Philip Morris USA, Inc., 2006 Cal. App. LEXIS 562 (Cal. Ct. App. Apr. $21,2006)$. In this factually analogous case, a California jury awarded plaintiff $\$ 850,000$ in compensatory damages and $\$ 28$ billion in punitive damages. $I d$. at ${ }^{*} 15$. The trial court reduced the punitive award to $\$ 28$ million and the California Court of Appeal affirmed, holding that the award - with its award-toharm ratio of thirty-three-to-one - properly comported with State Farm I. In so holding, the Bullock court notably diverged from Henley and took into account both the actual harm that defendant caused to plaintiff and the potential harm that it could have caused to the public at large. See, e.g., id. at *88-89 ("The evidence supports the conclusion ... that Philip Morris intended to dcceivc smokers and the public in general.") (emphasis added); id. at *89 (noting that plaintiff was "only one of many smokers affected by Philip Morris's nationwide efforts to disseminate misleading information and create a false controversy concerning the adverse health effects of smoking") (emphasis added).

1 am grateful to Robert Infelise for bringing this important and illustrative case to my attention in time for inclusion in this Comment. 
virtually identical facts. Williams was a wrongful death case in which an Oregon jury awarded plaintiff $\$ 821,485.80$ in compensatory damages and $\$ 79.5$ million in punitive damages. ${ }^{86}$ The trial court reduced plaintiff's compensatory award to $\$ 521,485.80$ and her punitive award to $\$ 32$ million. ${ }^{87}$ On appeal, the Oregon Court of Appeals reinstated plaintiff's original punitive damages award, holding that the $\$ 79.5$ million award--with a stunning award-to-harm ratio of ninety-six-to-one-was consistent with State Farm $I^{88}$ In so holding, the Williams court explicitly divided its award-to-harm analysis into two distinct parts. ${ }^{89}$ The first part addressed plaintiff's actual harm in a manner similar to the Henley court. ${ }^{90}$ The second part of the Williams court's analysis, however, focused on potential harm, something that the Henley court did not measure. According to the Williams court:

[T]he jury in assessing the amount of punitive damages was entitled to draw reasonable inferences as to the number of smokers in Oregon who had been defrauded [by defendant's promotional scheme] during the past decades and would be affected in the future by defendant's conduct, if that conduct were not deterred. ${ }^{91}$

Such potential harm, the Oregon court found, was sufficient to justify the unusually large award-to-harm-ratio between plaintiff's compensatory and punitive damages awards.

Williams and Henley represent two divergent ways in which courts have conducted award-to-harm ratio analyses in State Farm I's aftermath. ${ }^{92}$ The courts' positions in both of these cases are arguably consistent with the Supreme Court's punitive damages law, and both cases cite to this law for support of their holdings. ${ }^{93}$ But if the approaches used by both the Williams and Henley courts are, in fact, consistent with current law, then we find ourselves once again confronting the problem of uniformity. ${ }^{94}$ For all we

86. Williams, 92 P.3d 126, 130 (Or. Ct. App. 2004), affd, 2006 Ore. LEX1S 31 (Or. 2006).

87. Id.

88. Id. at $145-46$.

89. See id. at 145 (observing that two distinct types of harm were at issue in the case: "[f]irst, there is the harm to [plaintiff] .... Second, defendant inflicted potential harm on the members of the public in Oregon through its fraudulent promotional scheme").

90. See id. at $144-45$.

91. Id. (emphasis added); see also id. at 145 (observing that "it is difficult to conceive of more reprehensible misconduct ... to the Oregon public than what occurred in this case").

92. For an additional way to measure harm in the punitive damages context, see Exxon Valdez, 296 F. Supp. 2d 1071, 1103 (D. Alaska 2004) (suggesting that the types of harm that a court could take into account in assessing the constitutionality of a punitive damages award are: (1) plaintiffs' actual harm; (2) plaintiff's potential harm; and (3) any potential harm that defendant could have caused to the public at large).

93. The Williams and Henley courts, in conducting their respective award-to-harm ratio analyses, cited to identical portions of the Supreme Court's opinion in State Farm I. See Williams, 92 P.3d at 143-44; cf. Henley, 5 Cal. Rptr. 3d at 84.

94. See Cooper, 532 U.S. 424, 436 (2001). 
need to do is to examine Williams and Henley side-by-side to see that uniformity does not yet exist. If it did, it would have precluded the California and Oregon courts from reaching the fundamentally disparate results that they did in factually and legally analogous cases. Taken together, then, the Williams and Henley cases serve as stark indicators of the Supreme Court's failure to bring uniformity to its punitive damages law through its constitutionalization thereof.

\section{The Comparability Analysis: Civil Penalties and Criminal Sanctions}

The third $B M W$ factor examines comparable penalties and inquires into the following: (1) what types of penalties (civil or criminal) could defendant have incurred for similar misconduct, and (2) do those penalties bear a reasonable relationship to the punitive damages award that was, in fact, imposed in the case..$^{95}$ Courts justify the comparability analysis on fair notice grounds ${ }^{96}$ - that is, on grounds that a defendant should have advance warning not only of the fact that his misconduct could subject him to punishment, but also of the degree and magnitude of the punishment that could be leveled against him. ${ }^{97}$

Prior to State Farm I, courts looked to both civil and criminal penalties when assessing the reasonableness of punitive damages awards. ${ }^{98}$ In State Farm I, however, a majority of the Court limited lower courts' ability to consider criminal penalties. The majority noted that while criminal penalties had some bearing on the degree of seriousness with which courts viewed a defendant's misconduct, they were less useful when used to determine the dollar amount of a punitive damages award itself. In particular, the State Farm I majority cautioned against use of punitive damages awards as a way to circumvent the criminal process-with its corresponding constitutional safeguards - and to punish civil defendants for committing essentially criminal wrongs. ${ }^{99}$

95. See BMW, 517 U.S. 559, 583-84 (1996).

96. See State Farm I, 538 U.S. 408, 417 (2003); BMW, 517 U.S. at 574-75, 584; Exxon Valdez, 296 F. Supp. $2 \mathrm{~d}$ at 1107 (noting that in the comparability analysis, "the criminal (and civil) sanctions available are a useful double-check of what [defendant] reasonably would have understood was the outside limit of punishment that it could incur"); see also Zimmerman v. Direct Fed. Credit Union, 262 F.3d 70, 83 (1 st Cir. 2001); Inter Med. Supplies, Ltd. v. EB1 Med. Sys., Inc., 181 F.3d 446, 468 (3d Cir. 1999); Lee v. Edwards, 101 F.3d 805 (2d Cir. 1996); Waits v. City of Chicago, No. 01 C 4010, 2003 WL 21310277 (N.D. 11l. June 6, 2003).

97. See, e.g., Time Wamer Entm't Co. v. Six Flags Over Georgia, L.L.C., 563 S.E.2d 178, 186 (Ga. Ct. App. 2002) (upholding an award of punitive damages on grounds that "appellants received fair notice not only of the kind of conduct that would subject them to punishment, but also of the severity of the penalty that might be imposed").

98. See State Farm I, 538 U.S. at 428 (noting that "in the past, [the Supreme Court] ha[s] also looked to criminal penalties that could be imposed" on defendants in punitive damages cases); see also $B M W, 517$ U.S. at 583; Haslip, 499 U.S. 1, 23 (1991); Browning-Ferris Inds. of Vermont v. Kelco Disposal, lnc., 492 U.S. 257, 301 (1989) (O'Connor, J., concurring in part and dissenting in part).

99. State Farm I, 538 U.S. at 428. 
With respect to the comparability analysis, the State Farm I majority left two critical questions unanswered. First, although holding that courts should consider civil penalties when assessing the constitutionality of a punitive damages award, the majority did not explain what, precisely, "civil penalties" entail. More pointedly, the majority did not specify whether "civil penalties" were limited to the imposition of fines, or whether they included the potential for the loss of an operating license, as well. Second, the State Farm I majority left ambiguous the role of criminal penalties in the punitive damages analysis. While noting that criminal penalties were of "less utility" when used to assess the substance of a punitive damages award, the majority did not altogether ban lower courts from taking those penalties into consideration. ${ }^{100}$ Thus, post-State Farm I, a number of lower courts have continued to use criminal penalties in their punitive damages assessments. ${ }^{101}$ Other courts, however, have consciously shied away from this practice in light of State Farm I's ruling. ${ }^{102}$

The following section first attempts to illustrate the multitude of ways that lower courts have defined the term "civil penalties" in State Farm I's aftermath. It then argues that the lack of a clear definition for this term has contributed significantly to undercutting uniformity in the punitive damages law framework. Finally, this section addresses a related problem in the courts' use of criminal penalties.

\section{Civil Penalties: Fines, Revocation of License, or Both?}

The spirited dialogue between the U.S. and Utah Supreme Courts in the State Farm case offers a self-contained example of how amorphous the term "civil penalties" can be. Recall that in State Farm, a Utah jury leveled \$I45 million of punitive damages against defendant for fraud and bad faith. ${ }^{103}$ On appeal, the U.S. Supreme Court inquired into the disparity between this award and the "civil penalties authorized or imposed in comparable cases"104 and found that the most relevant civil penalty that could have been imposed was $\$ 10,000$ in fines, an amount "dwarfed by the \$I45 million punitive damages award" that was actually imposed. ${ }^{105}$ On that basis, the Court vacated the punitive damages award imposed against State Farm as violative of its substantive due process rights. ${ }^{106}$

\footnotetext{
100. Id.

101. See, e.g., Mathias v. Accor Econ. Lodging, lnc., 347 F.3d 672, 678 (7th Cir. 2003); Exxon Valdez, 296 F. Supp. 2d 1071, 1107 (D. Alaska 2004).

102. See, e.g., Romo v. Ford Motor Co., 6 Cal. Rptr. 3d 793, 812 (Cal. Ct. App. 2003); State Farm

II, 98 P.3d 409, 419 (Utah 2004).

103. State Farm $I I, 98$ P.3d at 419 .

104. State Farm I, 538 U.S. at 428.

105. Id.

106. Id. at 429 .
} 
On remand, the Utah Supreme Court took a broader view of "civil penalties." According to the Utah court, $\$ 10,000$ in fines was not the only civil penalty that could have been leveled against defendant for fraud and bad faith. ${ }^{107}$ Defendant could also have lost its license to operate within the state, a penalty that would surely have cost defendant more than the $\$ 10,000$ that it would otherwise have had to pay in civil fines. ${ }^{108}$ In the eyes of the Utah Supreme Court, the fact that defendant potentially stood to lose its license for its misconduct justified the imposition of a higher punitive damages award against it.

The discourse regarding the meaning of "civil penalties" between the State Farm courts set the stage for the judicial split that subsequently followed. After State Farm I, a number of lower courts tailored their definition of civil penalties to the definition adopted by the U.S. Supreme Court and constrained their comparability analysis to considerations of civil fines only. In Exxon Valdez, for example, the U.S. District Court for the District of Alaska reviewed a $\$ 5$ billion punitive damages award against defendant Exxon. ${ }^{109}$ 1n conducting its comparability analysis, the Exxon Valdez court examined a series of statutes imposing civil fines against organizations that spilled crude oil into Prince William Sound and concluded on the basis of those statutes that defendant had fair notice that it could incur "in excess of $\$ 5$ billion in . . civil penalties" for its spillage. ${ }^{110} 1 \mathrm{n}$ justifying the award against Exxon, however, the court did not allude to loss of license as a potential penalty that defendant could have incurred for its misconduct. ${ }^{111}$ Rather, it affirmed the essence of the punitive damages award on the basis of comparable fines alone. ${ }^{112}$

Other courts have been more receptive to the broader interpretation of "civil penalties" adopted by the Utah Supreme Court in State Farm II. This interpretation, which allows courts to consider both fines and the potentiality for the loss of license in its punitive damages analysis, has found

107. See State Farm II, 98 P.3d at 419.

108. See id.

109. See Exxon Valdez, 296 F. Supp. 2 d at 1082-83.

110. See id. at 1108-09.

111. Specifically, the court did not refer to the fact that Exxon could have lost its license for transporting crude oil; nor did it allude to the fact that Captain Hazelwood, commander of the Exxon Valdez at the time of the incident, could have lost his license for operating oil tankers. See id.

112. The Exxon Valdez court concluded that $\$ 5$ billion was not an excessive punitive damages award, but nevertheless reduced the award to $\$ 4.5$ billion in light of an express Ninth Circuit order for reduction. See id. at 1110-11. Defendant appealed again, and on January 27, 2006, the Ninth Circuit heard oral arguments for the second time regarding the constitutional propriety of the punitive damages award imposed against defendant Exxon. See Revised Notice, United States Court of Appeals for the Ninth Circuit, Location of Hearings for January Calendar 2, available at http://www.faegre.com/ articles/downform2.asp?doc_num $=7 \&$ aid $=751$ (last visited Feb. 17, 2006). For the full text of the oral arguments, see http://www.faegre.com/articles/downform2.asp?doc_num=9\&aid=751 (last visited Feb. $17,2006)$. 
support in at least one circuit. ${ }^{113}$ In Mathias $v$. Accor, plaintiffs checked into defendant's motel, which, unbeknownst to them, was infested with bedbugs. After checking out of the motel, plaintiffs sued defendant, claiming that defendant's knowing failure to address the bedbug problem constituted "willful and wanton misconduct" giving rise to a punitive damages claim. An lllinois jury agreed and awarded plaintiffs $\$ 372,000$ in punitive damages, despite the fact that plaintiffs' compensatory award totaled only $\$ 10,000 .^{114}$

The Seventh Circuit affirmed, holding that the punitive damages award was not excessive because defendant had fair notice that its failure to resolve its infestation problem could result in severe civil penalties. ${ }^{115}$ One such penalty was the revocation of defendant's operating license, which if imposed, would surely have cost defendant significantly more than what it would have to pay in punitive damages in the present case. ${ }^{116}$ In this regard, the Mathias court posited: "a Chicago hotel that permits unsanitary conditions to exist is subject to revocation of its license, without which it cannot operate .... We are sure that the defendant would prefer to pay the punitive damages assessed in this case than to lose its license."117 According to the Mathias court, then, the potentiality for the revocation of a license justifies the imposition of a higher punitive damages award against a defendant, provided that the defendant was eligible to have its license revoked for similar misconduct in the first instance. ${ }^{118}$

The U.S. Supreme Court's majority opinion in State Farm I, when viewed in conjunction with cases like Exxon Valdez, represents one interpretation of "civil penalties" in the punitive damages context. Under this interpretation, "civil penalties" are measured solely in terms of fines that a defendant could have incurred for similar misconduct. An alternative treatment of "civil penalties" is embodied in State Farm II and subsequent cases like Mathias. Under this more generous interpretation, courts ask the following two interrelated questions: what types of civil fines did defendant stand to incur for his misconduct, and did defendant also stand to lose his license for engaging in such misconduct? An affirmative answer to the latter question would justify the imposition of a higher punitive damages award than if the question was answered in the negative.

While both interpretations of "civil penalties" are arguably consistent with the Supreme Court's jurisprudence in this area, the two interpretations cannot coexist if uniformity is to be achieved in punitive damages law.

113. See, e.g., Mathias v. Accor, 347 F.3d 672 (7th Cir. 2003).

114. Id. at 674-75. The jury awarded $\$ 5,000$ in compensatory damages to each plaintiff.

115. See id. at 678 .

116. See id.

117. Id. Mathias's comparability analysis also included a discussion of relevant fines, but those fines are not pertinent to the present analysis because they arose in the criminal context. Id.

118. See id. 
This is because a court interpreting "civil penalties" strictly will almost always come to a different result on the comparability analysis than a court willing to take a more liberal interpretation of that same term. More to the point, a court measuring civil penalties in terms of both fines and the potentiality for the loss of license will almost always entertain a higher ceiling for what it considers to be an "excessive" or "unreasonable" punitive damages award than a court measuring civil penalties in terms of fines alone. This inconsistency in lower courts' treatment of civil penalties profoundly affects the manner in which these courts conduct their comparability analyses, which in turn, contributes to undercutting the broader uniformity in the application of punitive damages law.

\section{Criminal Penalties: More Utility, Less Utility, or No Utility?}

As problematic as lower courts' inconsistent treatment of civil penalties has been, there is an even deeper (and inextricably related) issue that divides lower courts conducting punitive damages reviews. This issue stems from the Supreme Court's failure to directly address the role of criminal penalties in the comparability analysis.

Recall that in State Farm I, a majority of the Supreme Court cryptically held criminal penalties to be of "less utility" when used to determine the dollar amount of a punitive damages award. ${ }^{119}$ A number of lower courts have interpreted this judicial pronouncement to mean that criminal penalties can no longer be considered at all in the comparability analysis. For example, in Romo v. Ford Motor Company, ${ }^{120}$ the California Court of Appeal read State Farm I to foreclose, in toto, its ability to consider the criminal penalties that could potentially have been leveled against defendant Ford for its alleged criminal negligence. ${ }^{121}$ To courts that have adopted the Romo view, then, the phrase "less utility" essentially means no utility, and criminal penalties are simply not a factor that courts consider in their punitive damages assessments. Though the Romo approach is undoubtedly alluring in its simplicity of application, it represents only one answer to the question of what role criminal penalties should play in the punitive damages context. Exxon Valdez and Mathias represent two additional, and vastly different, answers to the same question.

119. State Farm 1, 538 U.S. at 428.

120. Romo v. Ford Motor Co., 6 Cal. Rptr. 3d 793, 812 (Cal. Ct. App. 2003); see also Bocci v. Key Pharms., Inc., 76 P.3d 669, 675-76 (2003).

121. See Romo, 6 Cal. Rptr. 3d at 812 (opining that "[w]illful and conscious disregard of danger resulting in loss of life can constitute involuntary manslaughter...By the same token, the failure of prosecutors to seek criminal convictions in cases of the present sort does not permit an enhancement of the punitive damages award in a civil case.") (emphasis added). 
In Exxon Valdez, the Alaska district court acknowledged that State Farm I questioned the utility of criminal penalties, ${ }^{122}$ but nevertheless held such penalties to be of relevance in determining the constitutionality of punitive damages awards. ${ }^{123}$ According to the Exxon Valdez court, the nature and magnitude of criminal penalties are "a useful double-check on what [defendant] reasonably would have understood was the outside limit of punishment that it could incur . . ."124 Put simply, criminal penalties are relevant to punitive damages assessments to the extent that they are necessary to determine the question of notice-i.e., whether defendant had advance warning that its misconduct could subject it to punishment of a certain degree or magnitude. ${ }^{125}$

Mathias ventured one additional step beyond where Exxon Valdez was willing to go. In Exxon Valdez, the court acknowledged that State Farm I called into question the use of criminal penalties, and all but conceded that the plain text of the opinion indicated the Supreme Court's disapproval of their use. ${ }^{126}$ Mathias, on the other hand, interpreted the State Farm I opinion as giving a stamp of approval to the use of criminal penalties in the punitive damages context. ${ }^{127}$ To this effect, the Mathias court stated, "it would have been helpful had the parties presented evidence concerning the regulatory or criminal penalties to which the defendant exposed itself by deliberately exposing its customers to a substantial risk of being bitten by bedbugs. That is an inquiry recommended by the Supreme Court." ${ }^{128}$ According to the Mathias court, then, lower courts should utilize criminal penalties in their punitive damages analyses precisely because it is the Supreme Court's mandate that they do so.

This section of the Comment highlighted two ambiguities plaguing courts' comparability analyses. The first ambiguity arises out of the

122. See Exxon Valdez, 296 F. Supp. 2d 1071, 1106-07 (D. Alaska 2004) (noting that "[i]n State Farm, the [Supreme] Court dropped any reference to criminal penalties," and that "after State Farm, there has been some discussion as to whether comparable criminal penalties are still appropriate for consideration under the third [BMW] guidepost").

123. Id. at 1107-08.

124. Id. at 1107 .

125. See id. In the words of the Exxon Valdez court:

It is plainly ... not unreasonable to evaluate the constitutionality of a civil award of punitive damages in the light of what Exxon could have reasonably been on notice of had it considered the civil and criminal sanctions which could flow from the conduct in question. The actual criminal penalty imposed is not the proper criteria for the constitutional inquiry in which we are engaged. Our focus is the outer limit of potential sanctions that Exxon was Id. charged with knowing prior to the grounding of the Exxon Valdez.

126. See id. at 1106-07.

127. See Mathias, 347 F.3d 672, 678 (7th Cir. 2003).

128. Id. (emphasis added). In support of this assertion, the Seventh Circuit (incredibly) cited to State Farm I. Compare Mathias's use of State Farm I to Romo, where the California Court of Appeal cited State Farm I for support of the opposite supposition. See Romo v. Ford Motor Co., 6 Cal. Rptr. 3d 793, 812 (Cal. Ct. App. 2003). 
Supreme Court's failure to affix a uniform definition to the term "civil penalties." The second is attributable to the Court's failure to address the proper role of criminal penalties in the punitive damages framework. These two ambiguities have substantially undercut the Supreme Court's effort to bring uniformity and coherence to its punitive damages law through constitutionalization of this law. In hopes of overcoming the Court's failure, the next Part of this Comment proposes two recommendations, both of which are aimed at moving the current punitive damages framework towards a more uniform direction.

\section{III \\ RECOMMENDATIONS}

In Haslip, the Supreme Court held awards of punitive damages to be subject to the limitations of substantive due process. ${ }^{129}$ In $B M W$, the Court set forth a federalized standard for assessing the constitutional contours of punitive damages awards. ${ }^{130}$ In Cooper, the Court held that appellate courts must employ de novo review when evaluating awards of punitive damages for due process compliance. ${ }^{131}$ And finally, in State Farm I, the Court sought to provide structural clarity to the punitive damages framework that it has constructed over the years since Haslip first brought the issue within its constitutional purview. ${ }^{132}$ Though vastly different in their facts and outcomes, all of these cases share one crucial characteristic: all of them sought to bring a modicum of uniformity to the application of punitive damages law. Some, like $B M W$, attemptcd to do so through promulgating substantive legal rules; others, like Cooper, sought to do so through altering legal procedures. This Comment has thus far argued that cases like $B M W$, Cooper, and State Farm I have resoundingly failed to bring uniformity to the Supreme Court's punitive damages law. However, to say that the Supreme Court has failed is not enough; anyone can stand on the sidelines and condemn the Court for its alleged failures! Rectifying the Court's failures, however, require more than criticism; it requires the introduction of constructive proposals that are potentially more effective in addressing the underlying problem. The remainder of this section advances two such proposals: the first attempts to work within the current punitive damages framework, while the second advocates for the wholesale rejection of this framework. ${ }^{133}$

\footnotetext{
129. See Haslip, 499 U.S. 1, 23-24 (1991).

130. See BMW, 517 U.S. 559, 575-86 (1996).

131. See Cooper, 532 U.S. $424,435$.

132. See generally State Farm I, 538 U.S. 408 (2003).

133. These two proposals are, by their nature, mutually exclusive, and could only be implemented through fundamentally different constitutional frameworks. As will be made apparent through the subsequent analysis, the first proposal can only operate under a system in which defendants are afforded the substantive due process right to be free from "unreasonable" or "excessive" punitive
} 


\section{A. Recommendation One: An Analog to the Federal Sentencing Guidelines}

Recommendation One calls for the adoption of a system substantially similar to the system created by the Sentencing Reform Act, which Congress enacted in 1984. ${ }^{134}$ The Sentencing Reform Act created the United States Sentencing Commission, an independent body charged with the mandate of developing guidelines to narrow the "unwarranted disparities" in the sentencing of criminal defendants "with similar records [and] found guilty of similar criminal conduct ...."135 In discharging this mandate, the Commission promulgated the Federal Sentencing Guidelines Manual. ${ }^{136}$ This manual uses a unique system to: (i) assign numerical points to criminal offenses codified in the federal statutes, and (ii) provide for adjustments in light of aggravating and mitigating circumstances. ${ }^{137}$ The Guidelines are keyed to a corresponding table, which contains a grid with the "criminal history" category running along the horizontal axis (x-axis) and the "offense level" category running along the vertical axis (y-axis). ${ }^{138}$ A judge using this table in conjunction with the Guidelines need only calculate the offense level into which defendant's misconduct falls (a point on the $y$-axis), determine defendant's criminal history (a point on the $\mathrm{x}$-axis), and locate the place on the table at which these two points intersect. This calculation enables the judge to systematically determine the applicable sentencing range with respect to each particular criminal defendant. ${ }^{139}$

An analogous system, if implemented in the civil context, would not only provide civil defendants with the requisite degree of notice sufficient to satisfy the substantive due process inquiry, but, more significantly, would achieve the core objective of promoting uniformity. ${ }^{140}$ The following

damages awards. The second proposal, however, requires courts to reject the substantive due process right in the punitive damages context altogether.

134. See Pub. L. No. 98-473, ch. 2, 98 Stat. 1987 (1984).

135. 28 U.S.C. $\$ \$ 991(a),(b)(1)(B)(2000)$.

136. See United States Sentencing Commission Guidelines Manual (2004), available at http://www.ussc.gov/2004guid/gl2004pdf.

137. See id.

138. The sentencing table can be viewed at http://www.dcfpd.org/sentencing/sentencing_grid.pdf. One author provided a useful explanation of how the sentencing worked in practice:

The Guidelines utilize a sentencing table with 43 levels. Each level prescribes sentencing ranges that overlap with the ranges in thc preceding and succeeding levels. This table matches a sentencing range to the defendant's offense level. The vertical axis of the table, ranging from 1 to 43, represents the defendant's offense level. The horizontal axis displays the defendant's criminal history, based on the [sic] his or her past contacts with the criminal justice system. The intersection of the offense level and the criminal history rating determines the guideline range to be applied to the particular offender.

Rachel Konforty, Efforts to Control Judicial Discretion: The Problem of Aids and Sentencing, 1998 ANN. SuRv. AM. L. 49, 51-52 n.18 (1998) (citations omitted).

139. After United States v. Booke, the Federal Sentencing Guidelines can be applied only on an "advisory" basis. See 543 U.S. 220 (2005); see also supra note 14 and accompanying text.

140. See Cooper, 532 U.S. 424, 436 (2001). 
sections provide concrete suggestions for how a civil analog to the Federal Sentencing Guidelines could be used to facilitate uniformity in punitive damages law, and attempt to anticipate and address potential counterarguments made against use of such guidelines.

\section{Adapting the Federal Sentencing Guidelines to the Civil Context: Threshold Requirements}

A civil analog to the Federal Sentencing Guidelines must meet three basic threshold requirements. First and foremost, there must be drafters who are not only willing to undertake the painstaking task of drafting the proposed guidelines, but are also sufficiently knowledgeable in the area of punitive damages law, so that they are able to anticipate most, if not all, of the circumstances under which the issue of punitive damages may arise. ${ }^{141}$ Second, there must be the proposed guidelines themselves. While these guidelines should, by and large, parallel the Federal Sentencing Guidelines, they should also be tailored specifically to the civil context. In particular, the guidelines should: (1) clearly and comprehensively set forth the types of misconduct that would give rise to punitive damages claims, (2) assign numerical base values to each of these types of misconduct, and (3) enumerate aggravating and mitigating factors that would give rise to adjustments of the numerical base values. Finally, there must be the equivalent of a sentencing table, keyed to the proposed punitive damages guidelines. As noted above, under the current Federal Sentencing Guidelines, a judge can determine the range of a criminal defendant's sentence by locating the point on the sentencing grid at which the numerical values of defendant's offense level (y-axis) and criminal history (x-axis) intersect. A viable table in the punitive damages context must enable a judge to determine the range of a civil defendant's financial liability through an equally straightforward process.

\section{Creating Guidelines to Measure Punitive Damages Awards}

Up to this point, this section has mainly discussed what a civil analog to the Federal Sentencing Guidelines might look like in the abstract.

141. It is beyond the scope of this Comment to provide information and analyses on all of the organizations that are potentially well-suited to perform this task. However, one prime candidate is the American Law Institute (ALl), created in 1923 for the purpose of "promot[ingl the clarification and simplification of the law." See American Law Institute Home Page, http://www.ali.org. For an overview of the ALl's institutional structure, or a representative list of the ALl's current and ongoing projects, see $i d$.

It is also plausihle that Congress may choose to undertake the task of harmonizing punitive damages law through federal legislation. However, it is questionable whether, under the modern Commerce Clause, Congress would have the authority to do so. See U.S. Const. art. I, $\$ 8$, cl. 3; United States v. Morrison, 529 U.S. 598 (2000); United States v. Lopez, 514 U.S. 549 (1995). For a lucid and insightful article on the potential reach of the modern Commerce Clause, see Jesse H. Choper \& John C. Yoo, The Scope of the Commerce Clause After Morrison, 25 OKLa. City U. L. REv. 843 (2000). 
Perhaps a better way to foster understanding of Recommendation One is to illustrate how it would work in practice by applying it to an actual Supreme Court case. Such an illustration will not only help to place Recommendation One into a more appropriate context, but will also enable readers to review and critique actual template versions of the proposed guidelines, which this Comment puts forth.

\section{a. Templates: Methodology}

The following sections lay out the basic structure for the application of Recommendation One. Selected portions of the proposed punitive damages guidelines, set forth in Illustration 1, assign numerical values to a type of misconduct potentially giving rise to punitive damages claims and enumerate aggravating factors that render defendants eligible for upward adjustments. ${ }^{142}$ The corresponding tables (Tables $1 \& 2$ ) contain a numerical grid, to which the guidelines are keyed. The y-axis of the grid accounts for the "offense level" of defendant's misconduct, while the $\mathrm{x}$-axis accounts for the amount of compensatory damages that was leveled against defendant in a particular case. ${ }^{143} \mathrm{~A}$ judge using this grid in conjunction with the guidelines need only determine the offense level into which defendant's misconduct falls, calculate the amount of compensatory damages that was leveled against defendant, and locate the place on the grid at which these two points intersect. This simple calculation enables the judge to determine the range of punitive damages that a civil defendant may incur in any given case.

\section{b. Templates: Proposed Guidelines and Tables}

For purposes of the following illustration, take the facts of State Farm $I$, and assume the following conditions: ${ }^{144}$

(1) The American Law Institute (ALI) has recently completed drafting the Model Punitive Damages Guidelines (MPDG);

(2) The MPDG has been enormously influential and some version of it has been adopted by the Legislatures of all fifty states;

(3) The MPDG is keyed to Tables $1 \& 2$ (infra);

142. The template version of the proposed guidelines considers only aggravating factors, which give rise to upward adjustments of punitive damages awards. For brevity, mitigating factors potentially giving rise to downward adjustments are omitted. Recommendation One, however, does support the inclusion of both aggravating and mitigating factors and believe that both sets of factors have an appropriate place in a complete punitive damages analysis.

143. The category for "criminal history," which defined the $\mathrm{x}$-axis in the context of the Federal Sentencing Guidelines, is omitted here to accommodate the civil context. In its place, a category for compensatory damages is used. The "compensatory damages awarded" category ensures some reasonable relationship between the harm that defendant causes (measured in compensatory dollars) and the level of punishment ultimately imposed against him (measured in punitive dollars).

144. The feasibility of the assumed conditions is discussed in Part 11I.A.4, infra. 
(4) The MPDG consists of the provision enumerated in Illustration 1 (infra).

\section{Table 1 (Template) $)^{145}$}

Compensatory Damages Awarded

\begin{tabular}{|c|c|c|c|c|c|c|}
\hline $\begin{array}{l}\text { Offense } \\
\text { Level }\end{array}$ & $\begin{array}{c}I \\
\text { \$10K or less }\end{array}$ & $\begin{array}{c}I l \\
\$ 10 K-\$ 20 K \\
\end{array}$ & $\begin{array}{c}\text { III } \\
\$ 20 K-\$ 40 K \\
\end{array}$ & $\begin{array}{c}I V \\
\$ 40 K-\$ 80 K \\
\end{array}$ & $\begin{array}{c}V \\
\$ 80 \mathrm{~K}-\$ 160 \mathrm{~K} \\
\end{array}$ & $\begin{array}{c}V I \\
\$ 160 \mathrm{~K}-320 \mathrm{~K} \\
\end{array}$ \\
\hline 1 & $\$ 10 \mathrm{~K}$ or less & $\$ 10 \mathrm{~K}-\$ 20 \mathrm{~K}$ & $\$ 20 \mathrm{~K}-\$ 40 \mathrm{~K}$ & $\$ 40 \mathrm{~K}-\$ 80 \mathrm{~K}$ & $\$ 80 \mathrm{~K}-\$ 160 \mathrm{~K}$ & $\$ 160 \mathrm{~K}-\$ 320 \mathrm{~K}$ \\
\hline 2 & $\$ 10 \mathrm{~K}$ or less & $\$ 20 \mathrm{~K}-\$ 30 \mathrm{~K}$ & $\$ 40 \mathrm{~K}-\$ 60 \mathrm{~K}$ & $\$ 80 \mathrm{~K}-\$ 120 \mathrm{~K}$ & $\$ 160 \mathrm{~K}-\$ 240 \mathrm{~K}$ & $\$ 320 \mathrm{~K}-\$ 480 \mathrm{~K}$ \\
\hline 3 & $\$ 10 \mathrm{~K}-\$ 20 \mathrm{~K}$ & $\$ 30 \mathrm{~K}-\$ 40 \mathrm{~K}$ & $\$ 60 \mathrm{~K}-\$ 80 \mathrm{~K}$ & $\$ 120 \mathrm{~K}-\$ 160 \mathrm{~K}$ & $\$ 240 \mathrm{~K}-\$ 320 \mathrm{~K}$ & $\$ 480 \mathrm{~K}-\$ 640 \mathrm{~K}$ \\
\hline 4 & $\$ 20 \mathrm{~K}-\$ 30 \mathrm{~K}$ & $\$ 40 \mathrm{~K}-\$ 50 \mathrm{~K}$ & $\$ 80 \mathrm{~K}-\$ 100 \mathrm{~K}$ & $\$ 160 \mathrm{~K}-\$ 200 \mathrm{~K}$ & $\$ 320 \mathrm{~K} \cdot \$ 400 \mathrm{~K}$ & $\$ 640 \mathrm{~K}-\$ 800 \mathrm{~K}$ \\
\hline 5 & $\$ 30 \mathrm{~K}-\$ 40 \mathrm{~K}$ & $\$ 50 \mathrm{~K}-\$ 60 \mathrm{~K}$ & $\$ 100 \mathrm{~K}-\$ 120 \mathrm{~K}$ & $\$ 200 \mathrm{~K}-\$ 240 \mathrm{~K}$ & $\$ 400 \mathrm{~K}-\$ 480 \mathrm{~K}$ & $\$ 800 \mathrm{~K}-\$ 960 \mathrm{~K}$ \\
\hline 6 & $\$ 40 \mathrm{~K}-\$ 50 \mathrm{~K}$ & $\$ 60 \mathrm{~K}-\$ 70 \mathrm{~K}$ & $\$ 120 \mathrm{~K}-\$ 140 \mathrm{~K}$ & $\$ 240 \mathrm{~K}-\$ 280 \mathrm{~K}$ & $\$ 480 \mathrm{~K}-\$ 560 \mathrm{~K}$ & $\$ 960 \mathrm{~K}-\$ 1.12 \mathrm{M}$ \\
\hline 7 & $\$ 50 \mathrm{~K}-\$ 60 \mathrm{~K}$ & $\$ 70 \mathrm{~K}-\$ 80 \mathrm{~K}$ & $\$ 140 \mathrm{~K}-\$ 160 \mathrm{~K}$ & $\$ 280 \mathrm{~K}-\$ 320 \mathrm{~K}$ & $\$ 560 \mathrm{~K}-\$ 640 \mathrm{~K}$ & $\$ 1.12 \mathrm{M}-\$ 1.28 \mathrm{M}$ \\
\hline 8 & $\$ 60 \mathrm{~K}-\$ 70 \mathrm{~K}$ & $\$ 80 \mathrm{~K}-\$ 90 \mathrm{~K}$ & $\$ 160 \mathrm{~K}-\$ 180 \mathrm{~K}$ & $\$ 320 \mathrm{~K}-\$ 360 \mathrm{~K}$ & $\$ 640 \mathrm{~K}-\$ 720 \mathrm{~K}$ & $\$ 1.28 \mathrm{M}-\$ 1.44 \mathrm{M}$ \\
\hline 9 & $\$ 70 \mathrm{~K}-\$ 80 \mathrm{~K}$ & $\$ 90 \mathrm{~K}-\$ 100 \mathrm{~K}$ & $\$ 180 \mathrm{~K}-\$ 200 \mathrm{~K}$ & $\$ 360 \mathrm{~K}-\$ 400 \mathrm{~K}$ & $\$ 720 \mathrm{~K}-\$ 800 \mathrm{~K}$ & $\$ 1.44 \mathrm{M}-\$ 1.60 \mathrm{M}$ \\
\hline 10 & $\$ 80 \mathrm{~K}-\$ 90 \mathrm{~K}$ & $\$ 100 \mathrm{~K}-\$ 110 \mathrm{~K}$ & $\$ 200 \mathrm{~K}-\$ 220 \mathrm{~K}$ & $\$ 400 \mathrm{~K} \cdot \$ 440 \mathrm{~K}$ & $\$ 800 \mathrm{~K}-\$ 880 \mathrm{~K}$ & $\$ 1.60 \mathrm{M}-\$ 1.76 \mathrm{M}$ \\
\hline 11 & $\$ 90 \mathrm{~K}-\$ 100 \mathrm{~K}$ & $\$ 110 \mathrm{~K}-\$ 120 \mathrm{~K}$ & $\$ 220 \mathrm{~K}-\$ 240 \mathrm{~K}$ & $\$ 440 \mathrm{~K}-\$ 480 \mathrm{~K}$ & $\$ 880 \mathrm{~K}-\$ 960 \mathrm{~K}$ & $\$ 1.76 \mathrm{M}-\$ 1.92 \mathrm{M}$ \\
\hline 12 & $\$ 100 \mathrm{~K}-\$ 110 \mathrm{~K}$ & $\$ 120 \mathrm{~K}-\$ 130 \mathrm{~K}$ & $\$ 240 \mathrm{~K}-\$ 260 \mathrm{~K}$ & $\$ 480 \mathrm{~K}-\$ 520 \mathrm{~K}$ & $\$ 960 \mathrm{~K}-\$ 1.04 \mathrm{M}$ & $\$ 1.92 \mathrm{M}-\$ 2.08 \mathrm{M}$ \\
\hline 13 & $\$ 110 \mathrm{~K}-\$ 120 \mathrm{~K}$ & $\$ 130 \mathrm{~K}-\$ 140 \mathrm{~K}$ & $\$ 260 \mathrm{~K}-\$ 280 \mathrm{~K}$ & $\$ 520 \mathrm{~K}-\$ 560 \mathrm{~K}$ & $\$ 1.04 \mathrm{M}-\$ 1.12 \mathrm{M}$ & $\$ 2.08 \mathrm{M}-\$ 2.24 \mathrm{M}$ \\
\hline 14 & $\$ 120 \mathrm{~K}-\$ 130 \mathrm{~K}$ & $\$ 140 \mathrm{~K}-\$ 150 \mathrm{~K}$ & $\$ 280 \mathrm{~K}-\$ 300 \mathrm{~K}$ & $\$ 560 \mathrm{~K}-\$ 600 \mathrm{~K}$ & $\$ 1.12 \mathrm{M}-\$ 1.20 \mathrm{M}$ & $\$ 2.24 \mathrm{M}-\$ 2.40 \mathrm{M}$ \\
\hline 15 & $\$ 130 \mathrm{~K}-\$ 140 \mathrm{~K}$ & $\$ 150 \mathrm{~K}-\$ 160 \mathrm{~K}$ & $\$ 300 \mathrm{~K} \cdot \$ 320 \mathrm{~K}$ & $\$ 600 \mathrm{~K}-\$ 640 \mathrm{~K}$ & $\$ 1.20 \mathrm{M}-\$ 1.28 \mathrm{M}$ & $\$ 2.40 \mathrm{M}-\$ 2.56 \mathrm{M}$ \\
\hline
\end{tabular}

145. The ranges of numbers in Tables $1 \& 2$ are calculated by: (i) taking the number at the lower range of the compensatory award in the appropriate category, and (ii) multiplying that number by the relevant offense level. Take a Category 11 case, for example: the first range of numbers in Category II $(\$ 10 \mathrm{~K}-\$ 20 \mathrm{~K})$ is arrived at by multiplying the lower range of the compensatory award in that category $(\$ 10 \mathrm{~K})$ by Offense Level 1 , and then by Offense Level 2 ; the second range of numbers $(\$ 20 \mathrm{~K}-\$ 30 \mathrm{~K})$ is arrived at by multiplying the lower range of the compensatory award $(\$ 10 \mathrm{~K})$ by Offense Levcl 2 , and then, by Offense Level 3; and so on and so forth. 
Table 2 (Template)

Compensatory Damages Awarded

\begin{tabular}{|c|c|c|c|c|c|}
\hline $\begin{array}{l}\text { Offense } \\
\text { Level }\end{array}$ & $\begin{array}{c}V I I \\
\$ 320 K-\$ 640 K \\
\end{array}$ & $\begin{array}{c}V I I I \\
\$ 640 K-\$ I .3 M \\
\end{array}$ & $\begin{array}{c}I X \\
\$ 1.3 M-\$ 2.6 M \\
\end{array}$ & $\begin{array}{c}X \\
\$ 2.6 M-\$ 5.2 M \\
\end{array}$ & $\begin{array}{c}\bar{X} \\
\$ 5.2 M-\$ 10.4 M \\
\end{array}$ \\
\hline 1 & $\$ 320 \mathrm{~K}-\$ 640 \mathrm{~K}$ & $\$ 640 \mathrm{~K}-\$ 1.3 \mathrm{M}$ & $\$ 1.3 \mathrm{M}-\$ 2.6 \mathrm{M}$ & $\$ 2.6 \mathrm{M}-\$ 5.2 \mathrm{M}$ & $\$ 5.2 \mathrm{M}-\$ 10.4 \mathrm{M}$ \\
\hline 2 & $\$ 640 \mathrm{~K}-\$ 960 \mathrm{~K}$ & $\$ 1.3 \mathrm{M}-\$ 2.0 \mathrm{M}$ & $\$ 2.6 \mathrm{M}-\$ 3.8 \mathrm{M}$ & $\$ 5.2 \mathrm{M}-\$ 7.8 \mathrm{M}$ & $\$ 10.4 \mathrm{M}-\$ 15.6 \mathrm{M}$ \\
\hline 3 & $\$ 960 \mathrm{~K}-\$ 1.28 \mathrm{M}$ & $\$ 2.0 \mathrm{M}-\$ 2.7 \mathrm{M}$ & $\$ 3.9 \mathrm{M}-\$ 5.2 \mathrm{M}$ & $\$ 7.8 \mathrm{M}-\$ 10.4 \mathrm{M}$ & $\$ 15.6 \mathrm{M}-\$ 20.8 \mathrm{M}$ \\
\hline 4 & $\$ 1.28 \mathrm{M}-\$ 1.60 \mathrm{M}$ & $\$ 2.7 \mathrm{M}-\$ 3.4 \mathrm{M}$ & $\$ 5.2 \mathrm{M}-\$ 6.5 \mathrm{M}$ & $\$ 10.4 \mathrm{M}-\$ 13.0 \mathrm{M}$ & $\$ 20.8 \mathrm{M}-\$ 26.0 \mathrm{M}$ \\
\hline 5 & $\$ 1.60 \mathrm{M}-\$ 1.92 \mathrm{M}$ & $\$ 3.4 \mathrm{M}-\$ 4.1 \mathrm{M}$ & $\$ 6.5 \mathrm{M}-\$ 7.8 \mathrm{M}$ & $\$ 13.0 \mathrm{M}-\$ 15.6 \mathrm{M}$ & $\$ 26.0 \mathrm{M}-\$ 31.2 \mathrm{M}$ \\
\hline 6 & $\$ 1.92 \mathrm{M}-\$ 2.24 \mathrm{M}$ & $\$ 4.1 \mathrm{M}-\$ 4.8 \mathrm{M}$ & $\$ 7.8 \mathrm{M}-\$ 9.1 \mathrm{M}$ & $\$ 15.6 \mathrm{M}-\$ 18.2 \mathrm{M}$ & $\$ 31.2 \mathrm{M}-\$ 36.4 \mathrm{M}$ \\
\hline 7 & $\$ 2.24 \mathrm{M}-\$ 2.56 \mathrm{M}$ & $\$ 4.8 \mathrm{M}-\$ 5.5 \mathrm{M}$ & $\$ 9.1 \mathrm{M}-\$ 10.4 \mathrm{M}$ & $\$ 18.2 \mathrm{M}-\$ 20.8 \mathrm{M}$ & $\$ 36.4 \mathrm{M}-\$ 41.6 \mathrm{M}$ \\
\hline 8 & $\$ 2.56 \mathrm{M}-\$ 2.88 \mathrm{M}$ & $\$ 5.5 \mathrm{M}-\$ 6.2 \mathrm{M}$ & $\$ 10.4 \mathrm{M}-\$ 11.7 \mathrm{M}$ & $\$ 20.8 \mathrm{M}-\$ 23.4 \mathrm{M}$ & $\$ 41.6 \mathrm{M}-\$ 46.8 \mathrm{M}$ \\
\hline 9 & $\$ 2.88 \mathrm{M}-\$ 3.20 \mathrm{M}$ & $\$ 6.2 \mathrm{M}-\$ 6.9 \mathrm{M}$ & $\$ 11.7 \mathrm{M}-\$ 13.0 \mathrm{M}$ & $\$ 23.4 \mathrm{M}-\$ 26.0 \mathrm{M}$ & $\$ 46.8 \mathrm{M}-\$ 52.0 \mathrm{M}$ \\
\hline 10 & $\$ 3.20 \mathrm{M}-\$ 3.52 \mathrm{M}$ & $\$ 6.9 \mathrm{M}-\$ 7.6 \mathrm{M}$ & $\$ 13.0 \mathrm{M}-\$ 14.3 \mathrm{M}$ & $\$ 26.0 \mathrm{M}-\$ 28.6 \mathrm{M}$ & $\$ 52.0 \mathrm{M}-\$ 57.2 \mathrm{M}$ \\
\hline 11 & $\$ 3.52 \mathrm{M}-\$ 3.84 \mathrm{M}$ & $\$ 7.6 \mathrm{M}-\$ 8.3 \mathrm{M}$ & $\$ 14.3 \mathrm{M}-\$ 15.6 \mathrm{M}$ & $\$ 28.6 \mathrm{M}-\$ 31.2 \mathrm{M}$ & $\$ 57.2 \mathrm{M}-\$ 62.4 \mathrm{M}$ \\
\hline 12 & $\$ 3.84 \mathrm{M}-\$ 4.16 \mathrm{M}$ & $\$ 8.3 \mathrm{M}-\$ 9.0 \mathrm{M}$ & $\$ 15.6 \mathrm{M}-\$ 16.9 \mathrm{M}$ & $\$ 31.2 \mathrm{M}-\$ 33.8 \mathrm{M}$ & $\$ 62.4 \mathrm{M}-\$ 67.6 \mathrm{M}$ \\
\hline 13 & $\$ 4.16 \mathrm{M}-\$ 4.48 \mathrm{M}$ & $\$ 9.0 \mathrm{M}-\$ 9.7 \mathrm{M}$ & $\$ 16.9 \mathrm{M}-\$ 18.2 \mathrm{M}$ & $\$ 33.8 \mathrm{M}-\$ 36.4 \mathrm{M}$ & $\$ 67.6 \mathrm{M}-\$ 72.8 \mathrm{M}$ \\
\hline 14 & $\$ 4.48 \mathrm{M}-\$ 4.80 \mathrm{M}$ & $\$ 9.7 \mathrm{M}-\$ 10.4 \mathrm{M}$ & $\$ 18.2 \mathrm{M}-\$ 19.5 \mathrm{M}$ & $\$ 36.4 \mathrm{M}-\$ 39.0 \mathrm{M}$ & $\$ 72.8 \mathrm{M}-\$ 78.0 \mathrm{M}$ \\
\hline 15 & $\$ 4.80 \mathrm{M}-\$ 5.12 \mathrm{M}$ & $\$ 10.4 \mathrm{M}-\$ 11.1 \mathrm{M}$ & $\$ 19.5 \mathrm{M}-\$ 20.8 \mathrm{M}$ & $\$ 39.0 \mathrm{M}-\$ 41.6 \mathrm{M}$ & $\$ 78.0 \mathrm{M}-\$ 83.2 \mathrm{M}$ \\
\hline
\end{tabular}

\section{Illustration 1 (Template Guidelines) ${ }^{146}$}

$\S 1$. Aggravated Failure to Settle a Claim by an Insurer.

An insurer breaches its implied covenant of good faith and fair dealing towards the insured and becomes liable for punitive damages when it maliciously, wantonly, recklessly, deceptively, or in bad faith ${ }^{147}$ fails to accept a settlement offer within the liability limit of the insured's policy coverage. ${ }^{148}$

(a) Base Offense Level: 3

(b) Specific Offense Characteristics. ${ }^{149}$

146. These sections, which set forth the potential punitive damages liabilities of insurers, represent only a small fraction of the yet-to-be-completed guidelines. For brevity, template guidelines prescribing the punitive damages liabilities of defendants engaged in other types of misconduct are omitted.

147. Unless otherwise noted, the elements of malice, wantonness, recklessness, deception, or bad faith are to be read into all subsequent provisions of section 1 . This means that an insurer that fails to accept a settlement offer because of a bona fide dispute with the insured is not eligible to incur punitive damages, even if the insurcr appears to othcrwise satisfying all of the conditions in section 1.

148. See, e.g., State Farm Mut. Auto. Ins. Co. v. Smoot, 381 F.2d 331 (5th Cir. 1967) (holding that the insurer's willful and reckless disregard of the insured's rights properly gave rise to a punitive damages claim); Cain v. State Farm Mut. Auto. Ins. Co., 121 Cal. Rptr. 200 (Cal. Ct. App. 1975) (accord); cf. Shamblin v. Nationwide Mut. Ins. Co. 396 S.E.2d 766 (W. Va. 1990) (holding that no claim for punitive damages arises when the insurer does not settle the insured's claim due to a bona fidc dispute over the policy limit and there is no other evidence of malice or deliberate conduct on the part of the insurer).

149. The subsequent list of "specific offense characteristics" are drawn from the insurance liability case law of the various states. See supra note 148 and accompanying text. 


\section{Imposing Substantial Risks of Civil Liability Upon the Insured}

(1) If the insurer fails to accept a settlement offer ${ }^{150}$ under circumstances where it knows or should have known that: $(A)$ this failure is substantially likely to cause civil liability to be imposed against the insured; and $(B)$ damages arising out of such civil liability would more likely than not, exceed the insured's policy limit; increase by 2 levels.

(2) If the insurer fails to accept a settlement offer under circumstances where: $(A)$ the conditions of $(b)(1)$ are satisfied; and in addition $(B)$ the insurer knows or should have known that damages arising out of the insured's civil liability, would, more likely than not exhaust the insured's personal assets and force the insured into bankruptcy; increase by 3 levels. ${ }^{151}$

Fraud, Misrepresentation, or Non-Disclosure by the Insurer

(3) If the insurer: (A) does not accept a settlement offer, and also (B) fails to inform the insured that the settlement offer has been tendered; increase by 1 level.

(4) If the insurer: $(A)$ does not accept a settlement offer, and $(B)$ affirmatively conceals the fact that the settlement offer has been tendered from the insured; ${ }^{152}$ or $(C)$ affirmatively misrepresents the terms of the settlement offer to the insured; increase by 2 levels.

\section{Post-Judgment Failure to Accept Responsibility by the Insurer}

(5) If the insurer fails to accept a settlement offer under circumstances where: $(A)$ the conditions of $(b)(1)$ are satisfied; $(B)$ a judgment is subsequently leveled against the insured in an amount in excess of the insured's policy limit; and $(C)$ the insurer fails to accept responsibility for the excess judgment; increase by 1 level.

(6) If the insurer fails to accept a settlement offer under circumstances where: $(A)$ the conditions of $(b)(5)$ are satisfied; and in addition, $(B)$ the insurer's failure to accept responsibility for the excess judgment puts the

150. In the context of section 1 , and unless otherwise noted, the term "settlement offer" shall refer only to settlement offers the amount of which is within the liability limit of the insured's policy coverage.

151. To avoid duplicative awards, sections $1(b)(1)$ and $1(b)(2)$ should always be applied in the altemative, never concurrently; the cumulative adjustments from these two sections should, therefore, never exceed 3 levels.

152. Compare $\$ \mathrm{I}(\mathrm{b})(3)(\mathrm{B})$. An insurer may become eligible for an upward adjustment under section I(b)(3)(B) if the insurer simply fails to inform the insured that a settlement offer has been made. Section l(b)(4)(B) requires more: to become eligible for an upward adjustment under section I(b)(4)(B), an insurer must actually make some affirmative effort to conceal the fact that a settlement offer has been made from the insured. For example, if insurer A knows that a settlement offer has been tendered by the opposing party, but nevertheless informs the insured or the insured's counsel that no such settlement offer has been forthcoming, insurer A may become eligible for an upward adjustment under section $\mathrm{I}(\mathrm{b})(4)(\mathrm{B})$. 
insured's personal assets at substantial risk of loss; or (C) forces the insured into bankruptcy; increase by 3 levels. ${ }^{153}$

\section{Post-Judgment Rejection of Settlement Offer by the Insurer}

(7) If the insurer fails to accept a settlement offer under circumstances where: $(A)$ the conditions of $(b)(5)(A)$ and $(b)(5)(B)$ are satisfied, and in addition, $(B)$ fails to accept a post-judgment settlcment offer ${ }^{154}$ that would have cost the insurer less than what the judgment would have cost the insured; increase by 1 level.

(8) If the insurer fails to accept a settlement offer under circumstances where: $(A)$ the conditions of $(b)(7)$ are satisfied; and $(B)$ the insurer's failure to accept the post-judgment settlement offer puts the insured's personal assets at substantial risk of loss, or forces the insured into bankruptcy; and $(C)$ the insurer's acceptance of the post-judgment settlement offer would have, more likely than not, prevented the risk of such loss or bankruptcy; increase by 3 levels. ${ }^{155}$

\section{General Misconduct by the Insurer}

(9) If: $(A)$ the insurer fails to accept a settlement offer; and $(B)$ this failure occurs under circumstances that would render the insurer liable for an upward adjustment under $(b)(1)-(b)(8)$, and in addition, $(C)$ the insurer manifested an intent to vex, injure, or annoy the insured, or was recklessly indifferent with respect to causing such vexation, injury, or annoyance; increase by 1 level.

(10) If: (A) all of the conditions of $(b)(9)$ are satisfied, and (B) physical, mental, or emotional injuries to the insured result, and $(C)$ the injuries are proved through the testimonies of the insured's physician or another qualified witness, or through competent medical records; increase by 2 levels.

(11) If: (A) all of the conditions of (b)(9) are satisfied, and (B) substantial and provable economic injuries to the insured result; increase by 1 level.

153. To avoid duplicative awards, sections $1(b)(5)$ and $1(b)(6)$ should always be applied in the alternative, never concurrently; the cumulative adjustments from these two sections should, therefore, never excced 3 levels.

154. As distinguished from a conventional "settlement offer," a "post-judgment settlement offer" may include a settlement offer the amount of which exceeds the liability limit of the insured's policy coverage--so long as the offer was tendered after an adverse judgment had been entered against the insured. Compare "settlement offer" as defined in supra note 150.

155. To avoid duplicative awards, sections $1(b)(7)$ and $1(b)(8)$ should always be applied in the alternative, never concurrently; thc cumulative adjustments from these two sections should, therefore, never exceed 3 levels. 


\section{c. Templates: Application of the Proposed Punitive Damages Guidelines to State Farm I}

\section{i. Abbreviated Factual Summary}

In 1981, plaintiff caused a fatal automobile accident that resulted in the death of Todd Ospital. In the ensuing wrongful death action, plaintiff's insurer, State Farm, insisted that plaintiff was not responsible for the accident, maintaining this position despite overwhelming evidence to the contrary. Consequently, State Farm refused to accept a settlement offer from the Ospital Estate, which would have enabled State Farm to settle Ospital's claim for plaintiff's policy limit. Instead, State Farm assured plaintiff that his "assets were safe [and] that [he] had no liability for the accident" and then proceeded to take the case to trial. At trial, the jury found plaintiff liable for $\$ 184,849$ - an amount that exceeded plaintiff's policy limit by $\$ 135,849$. State Farm then refused to pay and advised plaintiff to sell his home in order to satisfy the judgment. Although State Farm ultimately paid the judgment, plaintiff nevertheless sued State Farm for bad faith. At trial, the jury awarded plaintiff $\$ 1$ million in compensatory damages and $\$ 145$ million in punitive damages. ${ }^{156}$

\section{ii. Application of the Proposed Punitive Damages Guidelines}

Before commencing an analysis of State Farm's punitive damages liability under the proposed guidelines, several things should be noted at the outset. ${ }^{157}$ First, irrespective of what its offense level is determined to be, the category for measuring State Farm's punitive damages eligibility on the "compensatory damages" side of the scale (x-axis) is VIII. This is because State Farm was held liable for $\$ 1$ million in compensatory damages, and Category VIII prescribes the eligibility for any defendant incurring compensatory damages in that amount (Table 3, x-axis, infra). Also, State Farm is eligible for incurring, at a minimum, punitive damages in a range between $\$ 2$ million and \$2.7 million. This is because the "base offense level" assigned to its misconduct (aggravated failure to settle a claim) is three, and any types of misconduct with that offense level is valued at between $\$ 2$ million and $\$ 2.7$ million in the VIII category (Table 3, y-axis, infra).

156. State Farm I, 538 U.S. 408, $412-15$ (2003).

157. Applying the proposed guidelines to State Farm I requires reference to Illustration 1 and Tables 1\&2, supra. 
Table 3 (State Farm: starting point)

\section{Compensatory Damages Awarded}

\begin{tabular}{|c|c|c|c|c|c|}
\hline $\begin{array}{l}\text { Offense } \\
\text { Level }\end{array}$ & $\begin{array}{c}V I I \\
\$ 320 K-\$ 640 K\end{array}$ & $\frac{V I I I}{3640 \mathrm{~K}-51.3 \mathrm{M}}$ & $\begin{array}{c}L X \\
\$ 1.3 M-\$ 2.6 M\end{array}$ & $\begin{array}{c}X \\
\$ 2.6 M-\$ 5.2 M\end{array}$ & $\begin{array}{c}X I \\
\$ 9.2 M-\$ 10.4 M\end{array}$ \\
\hline 1 & $\$ 320 \mathrm{~K}-\$ 640 \mathrm{~K}$ & $\$ 640 \mathrm{~K}-\$ 1.3 \mathrm{M}$ & $\$ 1.3 \mathrm{M}-\$ 2.6 \mathrm{M}$ & $\$ 2.6 \mathrm{M}-\$ 5.2 \mathrm{M}$ & $\$ 5.2 \mathrm{M}-\$ 10.4 \mathrm{M}$ \\
\hline 2 & $\$ 640 \mathrm{~K}-\$ 960 \mathrm{~K}$ & \$1.3M-\$2.0M & $\$ 2.6 \mathrm{M}-\$ 3.9 \mathrm{M}$ & $\$ 5.2 \mathrm{M}-\$ 7.8 \mathrm{M}$ & $\$ 10.4 \mathrm{M}-\$ 15.6 \mathrm{M}$ \\
\hline (8) & $\$ 960 \mathrm{~K}-\$ 1.28 \mathrm{M}$ & $\$ 2.0 \mathrm{M}-\$ 2.7 \mathrm{M}$ & $\$ 3.9 \mathrm{M} \cdot \$ 5.2 \mathrm{M}$ & $\$ 7.8 \mathrm{M}-\$ 10.4 \mathrm{M}$ & $\$ 15.6 \mathrm{M}-\$ 20.8 \mathrm{M}$ \\
\hline 4 & $\$ 1.28 \mathrm{M}-\$ 1.60 \mathrm{M}$ & $\$ 2.7 \mathrm{M}-\$ 3.4 \mathrm{M}$ & $\$ 5.2 \mathrm{M}-\$ 6.5 \mathrm{M}$ & $\$ 10.4 \mathrm{M}-\$ 13.0 \mathrm{M}$ & $\$ 20.8 \mathrm{M}-\$ 26.0 \mathrm{M}$ \\
\hline 5 & $\$ 1.60 \mathrm{M}-\$ 1.92 \mathrm{M}$ & $\$ 3.4 \mathrm{M}-\$ 4.1 \mathrm{M}$ & $\$ 6.5 \mathrm{M}-\$ 7.8 \mathrm{M}$ & $\$ 13.0 \mathrm{M}-\$ 15.6 \mathrm{M}$ & $\$ 26.0 \mathrm{M}-\$ 31.2 \mathrm{M}$ \\
\hline 6 & $\$ 1.92 \mathrm{M}-\$ 2.24 \mathrm{M}$ & $\$ 4.1 \mathrm{M}-\$ 4.8 \mathrm{M}$ & $\$ 7.8 \mathrm{M}-\$ 9.1 \mathrm{M}$ & $\$ 15.6 \mathrm{M}-\$ 18.2 \mathrm{M}$ & $\$ 31.2 \mathrm{M}+\$ 36.4 \mathrm{M}$ \\
\hline 7 & $\$ 2.24 \mathrm{M}-\$ 2.56 \mathrm{M}$ & $\$ 4.8 \mathrm{M}-\$ 5.5 \mathrm{M}$ & $\$ 9.1 \mathrm{M}-\$ 10.4 \mathrm{M}$ & $\$ 18.2 \mathrm{M}-\$ 20.8 \mathrm{M}$ & $\$ 36.4 \mathrm{M}-\$ 41.6 \mathrm{M}$ \\
\hline 8 & $\$ 2.56 \mathrm{M}-\$ 2.88 \mathrm{M}$ & $\$ 5.5 \mathrm{M}-\$ 6.2 \mathrm{M}$ & $\$ 10.4 \mathrm{M}-\$ 11.7 \mathrm{M}$ & $\$ 20.8 \mathrm{M}-\$ 23.4 \mathrm{M}$ & $\$ 41.6 \mathrm{M}-\$ 46.8 \mathrm{M}$ \\
\hline 9 & $\$ 2.88 \mathrm{M}-\$ 3.20 \mathrm{M}$ & $\$ 6.2 \mathrm{M}-\$ 6.9 \mathrm{M}$ & $\$ 11.7 \mathrm{M}-\$ 13.0 \mathrm{M}$ & $\$ 23.4 \mathrm{M}-\$ 26.0 \mathrm{M}$ & $\$ 46.8 \mathrm{M}-\$ 52.0 \mathrm{M}$ \\
\hline 10 & $\$ 3.20 \mathrm{M}-\$ 3.52 \mathrm{M}$ & $\$ 6.9 \mathrm{M}-\$ 7.6 \mathrm{M}$ & $\$ 13.0 \mathrm{M}-\$ 14.3 \mathrm{M}$ & $\$ 26.0 \mathrm{M}-\$ 28.6 \mathrm{M}$ & $\$ 52.0 \mathrm{M}-\$ 57.2 \mathrm{M}$ \\
\hline 11 & $\$ 3.52 \mathrm{M}-\$ 3.84 \mathrm{M}$ & $\$ 7.6 \mathrm{M}-\$ 8.3 \mathrm{M}$ & $\$ 14.3 \mathrm{M}-\$ 15.6 \mathrm{M}$ & $\$ 28.6 \mathrm{M}-\$ 31.2 \mathrm{M}$ & $\$ 57.2 \mathrm{M}-\$ 62.4 \mathrm{M}$ \\
\hline 12 & $\$ 3.84 \mathrm{M}-\$ 4.16 \mathrm{M}$ & $\$ 8.3 \mathrm{M}-\$ 9.0 \mathrm{M}$ & $\$ 15.6 \mathrm{M}-\$ 16.9 \mathrm{M}$ & $\$ 31.2 \mathrm{M}-\$ 33.8 \mathrm{M}$ & $\$ 62.4 \mathrm{M}-\$ 67.6 \mathrm{M}$ \\
\hline 13 & $\$ 4.16 \mathrm{M}-\$ 4.48 \mathrm{M}$ & $\$ 9.0 \mathrm{M}-\$ 9.7 \mathrm{M}$ & $\$ 16.9 \mathrm{M}-\$ 18.2 \mathrm{M}$ & $\$ 33.8 \mathrm{M}-\$ 36.4 \mathrm{M}$ & $\$ 67.6 \mathrm{M}-\$ 72.8 \mathrm{M}$ \\
\hline 14 & $\$ 4.48 \mathrm{M}-\$ 4.80 \mathrm{M}$ & $\$ 9.7 \mathrm{M}-\$ 10.4 \mathrm{M}$ & $\$ 18.2 \mathrm{M}-\$ 19.5 \mathrm{M}$ & $\$ 36.4 \mathrm{M}-\$ 39.0 \mathrm{M}$ & $\$ 72.8 \mathrm{M}-\$ 78.0 \mathrm{M}$ \\
\hline 15 & $\$ 4.80 \mathrm{M}-\$ 5.12 \mathrm{M}$ & $\$ 10.4 \mathrm{M}-\$ 11.1 \mathrm{M}$ & $\$ 19.5 \mathrm{M}-\$ 20.8 \mathrm{M}$ & $\$ 39.0 \mathrm{M}-\$ 41.6 \mathrm{M}$ & $\$ 78.0 \mathrm{M}-\$ 83.2 \mathrm{M}$ \\
\hline
\end{tabular}

With these preliminary facts in mind, we are ready to move on to a full analysis of State Farm's punitive damages eligibility. From the jury verdict, we know that State Farm is eligible to incur punitive damages under section 1 (aggravated failure to settle a claim) ${ }^{158}$ because it failed, in bad faith, to accept Ospital's settlement offer-an offer that was within the insured's policy limit. Therefore, we begin State Farm's punitive damages tally at three points. The next question is whether any aggravating factors give rise to upward adjustments of State Farm's "base" liability.

State Farm is likely to receive an upward adjustment of two levels under section 1(b)(1): it should have known that its failure to settle Ospital's claim would cause civil liability to be imposed against the insured and that damages arising out of such liability would likely exceed the insured's policy limit. This is so for several reasons. First, the State Farm trial court found that "a consensus was reached early on by the investigators and witnesses that [it was the insured's] unsafe pass [that] had . . . caused the crash." 159 Moreover, one of State Farm's own investigators-whose very job it was to dispute the insured's liability-had told State Farm that he believed plaintiff to be at fault for the accident and had recommended that State Farm settle the case with the Ospital Estate. ${ }^{160}$ Finally, State Farm knew that the Ospital Estate had a claim against plaintiff in wrongful death, where an adverse judgment in excess of $\$ 50,000$ (the insured's policy limit with State Farm) was virtually guaranteed. Under these circumstances, State Farm's refusal to settle with the Ospital

158. All sectional references are to Illustration I unless otherwise noted.

159. State Farm I, 538 U.S. at 413 (quoting Campbell v. State Farm Mut. Auto. Ins. Co., 65 P.3d 1134 (Utah 200 I)).

160. See id. 
Estate clearly implicates section 1(b)(1) and renders State Farm eligible for an upward adjustment of two levels. ${ }^{161}$

State Farm is also likely to receive an upward adjustment of three levels under section 1(b)(6). To be eligible for an upward adjustment under this section, State Farm must first satisfy the threshold requirements of section 1(b)(1). As discussed in the preceding section, State Farm satisfied these requirements. Additionally, section 1(b)(6) requires the following: (1) that a subsequent judgment be leveled against the insured in an anount in excess of the insured's policy limit; (2) that the insurer fail to accept responsibility for the excess judgment; and (3) such failure to accept responsibility puts the insured's personal assets at substantial risk of loss. ${ }^{162}$ After State Farm rejected the offer to settle with the Ospital Estate, it proceeded to take the insured's case to trial, where it lost. The jury then imposed $\$ 185,849$ of liability against the insured, an amount that was $\$ 135,849$ in excess of the insured's policy limit. State Farm refused to accept responsibility for this judgment and instead advised the insured to sell a personal asset-namely, his house - in order to "get things moving." 163 These facts, taken together, likely give rise to a section 1(b)(6) claim, thus causing State Farm to incur three additional points on its punitive damages tally. ${ }^{164}$

Finally, State Farm is likely to receive an upward adjustment of one level under section 1(b)(9). Section 1(b)(9) provides for upward adjustments in the following instances: (1) an insurer fails to accept a settlement offer within the insured's policy limit, (2) under circumstances that give rise to an upward adjustment under sections 1(b)(1)-(8), and additionally, (3) the insurer manifests an intent to vex, injure, or annoy the insured, or is recklessly indifferent with respect to causing such vexation, injury, or annoyance. The first and second conditions of section 1(b)(9) are clearly met. The issue, then, is whether condition three is satisfied as well. While it may be difficult to prove that State Farm intended to injure or annoy the insured, it is easily demonstrable that State Farm acted with reckless indifference in causing such injury or annoyance. After a fatal automobile accident, State Farm subjected the insured to the "risks and

161. Section $\mathrm{I}(\mathrm{b})(2)$ is not implicated under the facts as presented; there was no clear indication that paying the judgment would "exhaust" the insured's personal assets or force the insured into bankruptcy. Sections 1(b)(3)-(4) are similarly not implicated; there was no evidence that State Farm withheld news of the settlement offer, or made affirmative misrepresentations with respect to the terms of the offer, to the insured.

162. See lllustration 1 .

163. State Farm 1, 538 U.S. at 413.

164. Section $1(b)(5)$ is not being applied here because section $I(b)(6)$ is already being applied, and the proposed guidelines state that these two provisions should not apply concurrently. See lllustration l, $\S 1(b)(6)$, supra note 153 . Sections $1(b)(7)$ and $I(b)(8)$ are also not implicated because there was no post-judgment settlement offer at issue in State Farm 1 . 
rigors of a trial" that the insured was doomed to lose from the outset. ${ }^{165}$ Moreover, although State Farm assured the insured that his assets were safe prior to the trial, it did an abrupt about-face immediately thereafter, when it told him that it would not pay for the adverse judgment, and that the insured would have to sell his house instead. A reasonable insurer in State Farm's position would have realized that its actions were likely to cause severe mental injury, anguish, or annoyance to the insured. Therefore, State Farm is eligible to receive an additional upward adjustment of one level under section $1(\mathrm{~b})(9){ }^{166}$

\section{iii. A Final Tally of State Farm's Punitive Damages Liability}

Initially, State Farm began at a base offense level of three, making it eligible to incur punitive damages in an amount between \$2 and \$2.7 million. Several aggravating factors subsequently qualified State Farm for upward adjustments. State Farm incurred two points under section 1(b)(1), three points under section 1(b)(6), and one point under section 1(b)(9). These upward adjustments brought State Farm's offense level up to a total of nine. Under category VIll, a civil defendant whose misconduct has an offense level of nine is eligible to incur punitive damages in an amount between $\$ 6.2$ and $\$ 6.9$ million. Therefore, for its bad faith failure to settle its insured's claim, State Farm could be made to pay between $\$ 6.2$ and $\$ 6.9$ million under the proposed punitive damages guidelines (Table 4 , infra). ${ }^{167}$

165. See State Farm II, 98 P.3d 409, 416 (Utah 2004).

166. Section $1(\mathrm{~b})(10)$ is not implicated for lack of the requisite testimonies or medical records. Section $1(b)(11)$ is not implicated because State Farm had paid the adverse judgment prior to plaintiff's lawsuit. Therefore, no "substantial" economic injuries to plaintiff could be said to have resulted. See State Farm I, 538 U.S. at 414.

167. Compare this hypothetical award to the $\$ 9$ million that the Utah Supreme Court actually imposed in State Farm II. See 98 P.3d at 416. 
Table 4 (State Farm: final tally)

\section{Compensatory Damages Awarded}

\begin{tabular}{|c|c|c|c|c|c|}
\hline $\begin{array}{l}\text { Offense } \\
\text { Level }\end{array}$ & $\begin{array}{c}\text { VII } \\
\$ 320 \mathrm{~K}-\$ 640 \mathrm{~K}\end{array}$ & $\frac{\text { VIII }}{6640 \mathrm{~K}-\$ 1.3 \mathrm{M}}$ & $\begin{array}{c}\mathrm{DX} \\
\$ 1.3 \mathrm{M}-\$ 2.6 \mathrm{M}\end{array}$ & $\begin{array}{c}\mathrm{X} \\
\$ 2.6 \mathrm{M}-\$ 5.2 \mathrm{M} \\
\end{array}$ & $\begin{array}{c}\mathrm{XI} \\
\$ 5.2 \mathrm{M}-\mathrm{SI} 0.4 \mathrm{M}\end{array}$ \\
\hline I & $\$ 320 \mathrm{~K}-\$ 640 \mathrm{~K}$ & \$640K-\$I.3M & $\$ 1.3 \mathrm{M}-\$ 2.6 \mathrm{M}$ & $\$ 2.6 \mathrm{M}-\$ 5.2 \mathrm{M}$ & $\$ 5.2 \mathrm{M}-\$ 10.4 \mathrm{M}$ \\
\hline 2 & $\$ 640 \mathrm{~K}-\$ 960 \mathrm{~K}$ & \$I.3M-\$2.0M & $\$ 2.6 \mathrm{M}-\$ 3.9 \mathrm{M}$ & $\$ 5.2 \mathrm{M}-\$ 7.8 \mathrm{M}$ & $\$ 10.4 \mathrm{M}-\$ 15.6 \mathrm{M}$ \\
\hline 3 & $\$ 960 \mathrm{~K}-\$ 1.28 \mathrm{M}$ & $\$ 2.0 \mathrm{M}-\$ 2.7 \mathrm{M}$ & $\$ 3.9 \mathrm{M}-\$ 5.2 \mathrm{M}$ & $\$ 7.8 \mathrm{M}-\$ 10.4 \mathrm{M}$ & $\$ 15.6 \mathrm{M}-\$ 20.8 \mathrm{M}$ \\
\hline 4 & $\$ 1.28 \mathrm{M}-\$ 1.60 \mathrm{M}$ & $\$ 2.7 \mathrm{M}-\$ 3.4 \mathrm{M}$ & $\$ 5.2 \mathrm{M}-\$ 6.5 \mathrm{M}$ & $\$ 10.4 \mathrm{M}-\$ 13.0 \mathrm{M}$ & $\$ 20.8 \mathrm{M}-\$ 26.0 \mathrm{M}$ \\
\hline 5 & $\$ 1.60 \mathrm{M}-\$ 1.92 \mathrm{M}$ & $\$ 3.4 \mathrm{M}-\$ 4$. IM & $\$ 6.5 \mathrm{M}-\$ 7.8 \mathrm{M}$ & $\$ 13.0 \mathrm{M}-\$ 15.6 \mathrm{M}$ & $\$ 26.0 \mathrm{M}-\$ 31.2 \mathrm{M}$ \\
\hline 6 & $\$ 1.92 \mathrm{M}-\$ 2.24 \mathrm{M}$ & $\$ 4.1 \mathrm{M}-\$ 4.8 \mathrm{M}$ & $\$ 7.8 \mathrm{M}-\$ 9.1 \mathrm{M}$ & $\$ I 5.6 \mathrm{M}-\$ 18.2 \mathrm{M}$ & $\$ 31.2 \mathrm{M}-\$ 36.4 \mathrm{M}$ \\
\hline 7 & $\$ 2.24 \mathrm{M}-\$ 2.56 \mathrm{M}$ & $\$ 4.8 \mathrm{M}-\$ 5.5 \mathrm{M}$ & $\$ 9.1 \mathrm{M}-\$ 10.4 \mathrm{M}$ & $\$ 18.2 \mathrm{M}-\$ 20.8 \mathrm{M}$ & $\$ 36.4 \mathrm{M}-\$ 41.6 \mathrm{M}$ \\
\hline 8 & $\$ 2.56 \mathrm{M}-\$ 2.88 \mathrm{M}$ & $\$ 5.5 \mathrm{M}-\$ 6.2 \mathrm{M}$ & $\$ 10.4 \mathrm{M}-\$ 11.7 \mathrm{M}$ & $\$ 20.8 \mathrm{M}-\$ 23.4 \mathrm{M}$ & $\$ 41.6 \mathrm{M}-\$ 46.8 \mathrm{M}$ \\
\hline B & $\$ 2.88 \mathrm{M}-\$ 3.20 \mathrm{M}$ & $56.2 \mathrm{M}-\$ 6.9 \mathrm{M}$ & $\$ 11.7 \mathrm{M}-\$ 13.0 \mathrm{M}$ & $\$ 23.4 \mathrm{M}-\$ 26.0 \mathrm{M}$ & $\$ 46.8 \mathrm{M}-\$ 52.0 \mathrm{M}$ \\
\hline 10 & $\$ 3.20 \mathrm{M}-\$ 3.52 \mathrm{M}$ & $\$ 6.9 \mathrm{M}-\$ 7.6 \mathrm{M}$ & $\$ 13.0 \mathrm{M}-\$ 14.3 \mathrm{M}$ & $\$ 26.0 \mathrm{M}-\$ 28.6 \mathrm{M}$ & $\$ 52.0 \mathrm{M}-\$ 57.2 \mathrm{M}$ \\
\hline $1 \mathrm{I}$ & $\$ 3.52 \mathrm{M}-\$ 3.84 \mathrm{M}$ & $\$ 7.6 \mathrm{M}-\$ 8.3 \mathrm{M}$ & $\$ 14.3 \mathrm{M}-\$ 15.6 \mathrm{M}$ & \$28.6M-\$31.2M & $\$ 57.2 \mathrm{M}-\$ 62.4 \mathrm{M}$ \\
\hline 12 & $\$ 3.84 \mathrm{M}-\$ 4.16 \mathrm{M}$ & $\$ 8.3 \mathrm{M}-\$ 9.0 \mathrm{M}$ & $\$ 15.6 \mathrm{M}-\$ 16.9 \mathrm{M}$ & $\$ 31.2 \mathrm{M}-\$ 33.8 \mathrm{M}$ & $\$ 62.4 \mathrm{M}-\$ 67.6 \mathrm{M}$ \\
\hline 13 & $\$ 4 . \mathrm{I} 6 \mathrm{M}-\$ 4.48 \mathrm{M}$ & $\$ 9.0 \mathrm{M}-\$ 9.7 \mathrm{M}$ & $\$ 16.9 \mathrm{M}-\$ 18.2 \mathrm{M}$ & $\$ 33.8 \mathrm{M}-\$ 36.4 \mathrm{M}$ & $\$ 67.6 \mathrm{M}-\$ 72.8 \mathrm{M}$ \\
\hline 14 & $\$ 4.48 \mathrm{M}-\$ 4.80 \mathrm{M}$ & $\$ 9.7 \mathrm{M}-\$ 10.4 \mathrm{M}$ & $\$ 18.2 \mathrm{M}-\$ 19.5 \mathrm{M}$ & $\$ 36.4 \mathrm{M}-\$ 39.0 \mathrm{M}$ & $\$ 72.8 \mathrm{M}-\$ 78.0 \mathrm{M}$ \\
\hline 15 & $\$ 4.80 \mathrm{M}-\$ 5.12 \mathrm{M}$ & $\$ 10.4 \mathrm{M}-\$ 11.1 \mathrm{M}$ & $\$ 19.5 \mathrm{M}-\$ 20.8 \mathrm{M}$ & $\$ 39.0 \mathrm{M}-\$ 41.6 \mathrm{M}$ & $\$ 78.0 \mathrm{M}-\$ 83.2 \mathrm{M}$ \\
\hline
\end{tabular}

\section{Advantages to Adopting Recommendation One}

There are compelling reasons to forego the preexisting legal standard on punitive damages law and to adopt, in its place, a standard more analogous to the Federal Sentencing Guidelines, as proposed by Recommendation One. The most compelling reason for this is the commonality of purpose. Congress adopted the Federal Sentencing Guidelines to address precisely the same problem that the Supreme Court set out to resolve when it constitutionalized the law of punitive damages: the problem of the lack of uniformity. ${ }^{168}$ Adopting the system proposed by Recommendation One would, moreover, be effective in promoting uniformity. Instead of being forced to grapple with inherently elusive concepts like reprehensibility, potential harm, and comparable penalties, judges, under the proposed system, would have more concrete and objective criteria for adjudging the constitutional propriety of punitive damages awards.

Finally, adopting the system described in Recommendation One would ensure that civil defendants are put on notice, not only of the types of conduct that could subject them to punishment, but also of the severity of the punishment that could be leveled against them. While the notion of fair notice has been something to which the U.S. Supreme Court has consistently paid lip service, ${ }^{169}$ the Court's current punitive dannages

168. Compare Cooper, 532 U.S. at 436 (holding that requiring appellate courts to engage in de novo review of punitive damages awards "help to assure the uniform general treatment of similarly situated persons that is the essence of law itself") (quoting BMW, 517 U.S. 559, 587 (1996) (Breyer, J., concurring)), with 28 U.S.C. $\S 991(\mathrm{~b})(1)(B)$ (2000) (noting that the purpose of the Sentencing Guidelines is to "provide certainty and faimess in meeting the purposes of sentencing [and] avoiding unwarranted sentencing disparities among defendants with similar records who have been found guilty of similar criminal conduct").

169. See, e.g., $B M W, 517$ U.S. at 574 ("Elementary notions of fairness enshrined in our constitutional jurisprudence dictate that a person receive fair notice not only of the conduct that will subject him to punishment, but also of the severity of the punishment that a State may impose."). 
jurisprudence fails to provide such notice. Far too often, we encounter the type of situation that arose in Henley and Williams, ${ }^{170}$ where civil defendants in factually and legally analogous cases are subjected to drastically differing levels of punishment for no clear, articulable reason. Because Recommendation One provides guidelines that would enable civil defendants to assess their own conduct and calculate their own punitive damages liabilities well in advance of any lawsuits, the adoption of this recommendation would effectively eliminate the problem of fair notice from the substantive due process inquiry altogether.

\section{Potential Counterarguments Against the Adoption of Recommendation One}

To say simply that we should replace the preexisting legal standard on punitive damages law with the standard of Recommendation One, however, is hardly sufficient. Substantial obstacles stand in the way of practical implementation and this Comment cannot hope to address all of them. However, this Comment can point out some of the most glaring problems with Recommendation One-problems that must, without a doubt, be resolved before implementation can take place. The subsequent sections discuss some of these problems, while simultaneously acknowledging that prescribing comprehensive solutions for each fall beyond the scope of this Comment.

As a threshold matter, we inust discuss why we should import concepts from the Federal Sentencing Guidelines into the civil context, particularly given the fact that the Sentencing Guidelines have been the object of so much criticism themselves. Specifically, courts and commentators have criticized the Guidelines on three grounds. They claim, and the Supreme Court has recently agreed, that mandatory application of the Sentencing Guidelines violates criminal defendants' Sixth Amendment right to jury trial because the Guidelines allow judges to engage in additional fact-finding on a preponderance of evidence standard after the jury had rendered its verdict. ${ }^{171}$ This argument is inapposite in the punitive damages context for two reasons. For one, the Sixth Amendment is unique to criminal trials and is not triggered by civil litigation. ${ }^{172}$ Additionally, judicial fact-finding on a preponderance of evidence standard does not violate civil defendants' right to jury trial under the Seventh Amendment, because the preponderance standard is, in fact, the constitutionally-prescribed standard for most civil proceedings in the first place. ${ }^{173}$

170. See discussion supra in Part II.B.1-3.

171. The Supreme Court accepted this argument in United States v. Booker, 543 U.S. 220 (2005).

172. See U.S. Const. amend. VI ("In all criminal prosecutions, the accused shall enjoy the right to a speedy and public trial, by an impartial jury ....") (emphasis added).

173. See U.S. CoNSt, amend. VII. 
Courts and commentators also argue that the Sentencing Guidelines eliminate judicial discretion, forcing judges to impose long sentences that neither fit the crime nor comport with notions of fairness and justice. Several rejoinders can be made to this argument as it applies to punitive damages law. When the Supreme Court constitutionalized the law of punitive damages, its purpose in doing so was to bring uniformity to this body of law. Guidelines that curb the judiciary's ability to consider individualized circumstances allow for such uniformity and are thus consistent with the Court's mandates in Haslip, BMW, Cooper, and State Farm I. Moreover, attempting to introduce notions of individualized justice into the civil context inevitably leads to forum shopping. Plaintiffs seeking to recover higher measures of punitive damages under an "individualized" system would have ample opportunity to stack litigation odds in their favor by bringing lawsuits in jurisdictions where the judges are sympathetic to their plight and avoiding jurisdictions where judges are prone to examining the "individualized" circumstances of defendants.

Relatedly, courts and commentators argue that the Sentencing Guidelines do not eliminate discretion in criminal sentencing, but merely shift the discretion from judges to prosecutors, who are often more invested in the outcomes of cases. ${ }^{174}$ This criticism of the Guidelines loses much of its force in the civil context, where no unilateral "charging" decisions are made ${ }^{175}$ and civil defendants often come to the table with much more bargaining power than their criminal counterparts, and are, correspondingly, much less susceptible to being coerced or manipulated into accepting settlement offers against their interests.

Recommendation One also fails to address several other questions. First, even assuming that all agree that guidelines should be drafted to promote uniformity in punitive damages law (a huge assumption in itself), who should undertake the formidable task of drafting those guidelines? Writing bits and pieces of the guidelines in the formative stage may be easy, ${ }^{176}$ but designing an appropriate provision for every situation where a claim of punitive damages may arise is a significantly more daunting task; and it is not clear at this stage whether anyone is actually willing to undertake this challenge, although the American Law Institute (ALl) is uniquely well-equipped to do so. ${ }^{177}$ Second, and related, even in the event that punitive damages guidelines are drafted, how can we be sure that they will be embraced by the legislatures of all, or at least a majority, of the fifty

174. See, e.g., Lisa M. Farabee, Disparate Departures Under the Federal Sentencing Guidelines: A Tale of Two Districts, 30 CoNN. L. REv. 569, 577-81 (1998).

175. While it is plausible that civil plaintiffs may manipulate their claims in ways most likely to maximize their chances for punitive damage recovery, civil defendants remain free to challenge the sufficiency of potentially frivolous claims through pre-trial motions.

176. See lllustration 1.

177. See supra note 141 and accompanying text. 
states? ${ }^{178}$ This question is important because punitive damages law derives almost exclusively from the common law and is extraordinarily statespecific, subject only to the limitations of the federal Constitution. Therefore, if guidelines are to be effective in promoting uniformity, they must be widely adopted by the states and scrupulously applied by state courts.

A third question that Recommendation One does not address is the issue of permissibility - that is, whether guidelines of the type proposed by Recommendation One are a constitutionally legitimate way of addressing the uniformity problem. The existence of the Federal Sentencing Guidelines suggests that such guidelines pose no problem of constitutional magnitude so long as they are applied on an "advisory" basis. ${ }^{179}$ On the other hand, the Supreme Court's longstanding reluctance to adopt any type of mathematical formula in punitive damages law casts at least some doubt upon the permissibility of this practice. ${ }^{180}$

The final question is one that Recommendation One does implicitly address, but probably, not to the satisfaction of certain segments of the legal community. In simple terms, this question can be phrased as follows: if we give civil defendants the means to ascertain exactly how much punishment they may incur ex ante, what is to stop them from simply passing on those costs as the costs of doing business? This dilemma, unique to the civil context, relates to the precarious balance that must be struck between promoting uniformity and using uncertainty to deter civil defendants from engaging in potentially egregious wrongs.

Recommendation One strikes the balance in favor of uniformity. However, it does so not because it wants to confer tacit endorseinent upon civil defendants for their misconduct, or to encourage those defendants to engage in such misconduct whenever they decide that it is financially "worth it" to do so. Rather, Recommendation One strikes the balance in favor of uniformity because the Due Process Clause of the Constitution requires it. The Supreme Court has long held that the Due Process Clause incorporates within its scope of protections the right of a defendant to fair notice-notice with respect not only to the types of conduct that may subject him to punishment but also to the severity of the punishment that may

178. For a brief discussion of why Congress arguably lacks the authority to harmonize punitive damages law through federal legislation, see supra note 141.

179. See United States v. Booker, 543 U.S. 220 (2005).

180. For example, in $B M W$, the Court noted that it has "consistently rejected the notion that the constitutional line [for punitive damages awards] is marked by a simple mathematical formula ...." 517 U.S. 559, 582 (1996). In the more recent case of State Farm I, howcver, the Court demonstrated a greater willingness to speak in terms of concrete numbers when it conceded that "in practice, few awards exceeding a single-digit ratio between punitive and compensatory damages, to a significant degree, will satisfy due process." 538 U.S. 408, 425 (2003) (emphasis added). If the current trend holds, it seems at least arguable that the Court may soon be open to hearing about, and perhaps accepting, the type of numeric-based system proposed by Recommendation One. 
reasonably be leveled against him. ${ }^{181}$ In light of this judicial pronouncement, it would seem that although the arbitrary imposition of punitive damages may be the most effective means of promoting the policy goal of deterrence, the Constitution prohibits the precise use of that arbitrariness as a weapon to deter civil defendants ex ante. And where conflict exists between policy and constitutional prohibition, constitutional prohibition will — for better or worse-trump policy, even sound policy, at any time.

B. Recommendation Two: Due Process Means Due Processthe Fourteenth Amendment as a Vehicle for Protecting Civil Defendants' Procedural Rights

Recommendation One attempts to work within the current legal framework for assessing the constitutionality of punitive damages awards. It assumes that substantive due process applies in the punitive damages context without examining the deeper issue of whether it should be thus applied. Recommendation Two squarely challenges this assumption, arguing that substantive due process should not be a right afforded to civil defendants in the punitive damages arena. To the contrary, the right of due process should operate solely as a procedural safeguard, which does no more than afford civil defendants the right to challenge punitive damages awards in state courts. Under this interpretation of the Due Process Clause, a civil defendant has no federal constitutional right that the amount of punitive damages leveled against him be "reasonable." His sole right is to the fairness of the procedure through which the award is imposed. This view of the Due Process Clause is favored by Justices Scalia ${ }^{182}$ and Thomas, ${ }^{183}$ and to a lesser degree, by Justice Ginsburg. ${ }^{184}$

Honda Motor Co. v. Oberg provides an example of how Recommendation Two would work in practice. ${ }^{185}$ In Oberg, a design defect case, an Oregon jury awarded plaintiff $\$ 5$ million in punitive damages. ${ }^{186}$ The Oregon Court of Appeals and Oregon Supreme Court upheld the verdict on the basis of a state statute, which prohibited judicial review of juryimposed punitive damages awards unless there was "no evidence" to support the verdict giving rise to the award. ${ }^{187}$ The U.S. Supreme Court reversed, holding that Oregon's statute failed to provide defendant with

181. See, e.g., BMW, 517 U.S. at 574 n.22; State Farm I, 538 U.S. at 417; see also Mathias, 347 F.3d 672, 676 (7th Cir. 2003); Time Warner Entm't Co., S63 S.E.2d 178, 186 (Ga. Ct. App. 2002).

182. See BMW, 517 U.S. at 598-99 (Scalia, J., dissenting).

183. See State Farm I, 538 U.S. at 429-30 (Thomas, J., dissenting).

184. See generally BMW, 517 U.S. at 607-14 (Ginsburg, J., dissenting).

185. 512 U.S. 415 (1994).

186. See id.

187. See id. at 418-19; see also id. at 427 (noting that Oregon only allowed judicial review of a punitive damages award if the award was based on improper jury instructions or trial error, or if there was simply no evidence to support the imposition of the award). 
adequate post-verdict judicial review, and thus offered insufficient protection against potentially arbitrary deprivations of property. ${ }^{188}$ In other words, the Court found Oregon's procedure for imposing punitive damages awards to be violative of defendant's (procedural) due process rights.

Oberg exemplifies the extent of the analysis federal courts would be required to engage in under Recommendation Two. Under this recommendation, federal courts would no longer need to conduct substantive assessments of "excessiveness," nor grapple with inherently subjective inquiries into reprehensibility, harm, or comparability. Rather, all federal courts would need to do in assessing awards of punitive damages on appeal is to ensure the fairness of the state-prescribed procedure through which the award was imposed-i.e., ensure that the procedure properly limited the factors that the jury could consider in determining the amount of the award and provided defendant with meaningful post-verdict judicial review of the adverse judgment. ${ }^{189}$

There are several advantages to adopting Recommendation Two's approach to punitive damages law. To begin, this approach is supported by long-established precedent and legal history. Prior to the Supreme Court's decision in Haslip, substantive assessments of punitive damages awards had always been a discretionary function of the state courts, consistently performed by those courts with minimal federal intervention. ${ }^{190}$ Additionally, there are good policy reasons for leaving substantive punitive damages assessments in states' hands. Arguably, no area of law is more fact-specific than the law of torts, and no standard of judgment more dependent on the sentiments of a community than the standard of the "reasonable person." ${ }^{\text {"191 }}$ Consequently, when we take tort judgments away from state judges and juries who are intimately familiar with the facts and community sentiments surrounding a case and subject those judgments to the de novo review of the federal appellate courts, it is not clear that the ultimate decisions of those courts are more reflective of our sense of justice. This is not because federal judges are any less committed to doing justice than their state counterparts, but simply because, in state tort cases, federal judges will inevitably be further removed from both the facts of the case and the sentiments of the community in which the case was decided. This inevitability is what prompted Justice Scalia to criticize $B M W$ as a

188. See id. at 420,432 .

189. See id. at 420; Haslip, 499 U.S. 1, 18-19 (1991).

190. See Chanenson \& Gotanda, supra note 16, at 449; see also St. Louis, Iron Mountain \& S. Ry. v. Williams, 251 U.S. 63 (1919); Beckwith v. Bean, 98 U.S. 266 (1878); Day v. Woodworth, 54 U.S. 363 (1852).

191. See $B M W, 517$ U.S. 559, 600 (1996) (Scalia, J., dissenting) (noting that "[a]t the time of adoption of the Fourteenth Amendment, it was well understood that punitive damages represent the assessment by the jury, as the voice of the community, of the measure of punishment the defendant deserved"). 
decision that "is really no more than a disagreement with the community's sense of indignation or outrage expressed in the punitive award of the Alabama jury ... [and reflective of] a judgment about the appropriate degree of indignation or outrage, which is hardly an analytical determination."192 That same inevitability underlies the proposed framework of Recommendation Two.

Implementation of Recommendation Two would also facilitate judicial efficiency and ease of administration. Currently, courts reviewing punitive damages awards on appeal must undergo the strenuous and timeconsuming process of measuring reprehensibility, potential harm, and comparable penalties under the federalized standard of $B M W$. They must also take into account the unique punitive damages law of the respective states from which their cases originated. ${ }^{193}$ Stripping punitive damages law of substantive due process considerations would enable both federal and state appellate courts to simplify their analysis. Under the system contemplated by Recommendation Two, state courts reviewing punitive damages awards on appeal would continue to apply their state-specific laws (both common and statutory) to assess the excessiveness of a punitive damages award but would no longer take into account the federalized standard of $B M W$.

Federal courts would play an even more limited role in the appellate process. Under Recommendation Two, federal courts reviewing punitive damages awards on appeal would concern themselves exclusively with monitoring state courts for procedural due process compliance. That is, federal courts would review punitive damages award judgments only to the extent necessary to ensure that the procedure through which the state imposed the judgment was fair. If the state procedure properly limited jury discretion and provided defendant with adequate post-verdict judicial review, then the requirements of due process are met and the award must be affirmed. In short, Recommendation Two reserves substantive punitive damages assessments to the states and takes federal courts out of the business of measuring "excessiveness" altogether.

\section{CONCLUSION}

Law, in general, is a fluid concept and punitive damages law is no exception. The standard of reprehensibility, for example, will always rest in the eye of the beholder, as will the standard of "reasonableness" in negligence, ${ }^{194}$ the standard of "unreasonableness" in search and seizure, ${ }^{195}$ and

192. $B M W, 517$ U.S. at 600 (Scalia, J., dissenting).

193. See, e.g., Hangarter v. Provident Life and Accident Ins. Co., 373 F.3d 998, 1013-15 (9th Cir. 2004) (assessing the constitutional propriety of a punitive damages award first under California state law, then under the federalized standard of $B M W$ ).

194. See Restatement (SECOND) OF TORTs $\S 283$ (1977). 
the standard of "prurience" in obscenity. ${ }^{196}$ Typically, we accept this fluidity as an inherent part of our legal system-a system that consists of juries and multiple courts of appeal, and a system that appears, at times, more emphatic about giving voice to the sentiments of thc community than with promoting overarching uniformity in the application of the law.

However, when a federal court affirmatively breaks with precedent and intervenes into an area of law traditionally reserved to the states for the explicit purpose of promoting uniformity, the concern becomes whether that court is, in fact, fulfilling its stated purpose. This Comment has argued that even though the U.S. Supreme Court ventured into the punitive damages arena for the very purpose of promoting uniformity in this area of law, it has resoundingly failed to achieve this purpose. The $B M W$ guideposts that the Court promulgated, while conferring an "artificial air of doctrinal analysis" upon punitive damages reviews, ${ }^{197}$ provided, at best, minimal guidance to lower courts conducting inquiries into excessiveness. And de novo review, instituted in Cooper ${ }^{198}$ did nothing more than shift the burden of assessing punitive damages awards from trial judges and juries intimately familiar with a case to appellate judges, who are not only further removed from the facts governing any particular case, but are also less familiar with the sentiments of the community in which the case was decided.

The first two Parts of this Comment examined the current legal standards governing punitive damages law and documented the multitude of ways that those standards have failed to bring uniformity to this body of law. Subsequent to detailing those failures, this Comment offered two recommendations for improving the state of punitive damages law. Recommendation One attempted to work within the preexisting legal framework and proposed an alternative way of promoting uniformity in punitive damages law. Specifically, Recommendation One called for the promulgation of guidelines that prescribed the range of punitive damages that a civil defendant may incur for engaging in various types of misconduct.

Recommendation Two differed from Recommendation One in that it did not attempt to work within the current punitive damages framework, but sought to challenge this framework on a fundamental level. Recommendation Two suggested that the question of whether uniformity could be achieved in punitive damages law is beside the point; the deeper issue is whether civil defendants should have a federal constitutional right not to have "excessive" or "unreasonable" punitive damages awards leveled against them in the first place. Ultimately, Recommendation Two

195. See U.S. Const. amend. IV.

196. Miller v. California, 413 U.S. 15 (1973).

197. See BMW, 517 U.S. at 606 (Scalia, J., dissenting).

198. See Cooper, 532 U.S. 424, 435 (2001). 
[Vol. 94:793

answered this question in the negative. In so doing, it effectively took substantive punitive damages assessments out of the federal realm and placed them back within the province of the states, where they historically had been, and where they arguably continue to belong. 